\title{
The chronology of Jäkärlä Ware - Bayesian interpretation of the old and new radiocarbon dates from Early and Middle Neolithic southwest Finland
}

\author{
Petro Pesonen ${ }^{1}$, Markku Oinonen ${ }^{2}$ \\ 1 Department of Biology, University of Turku, Turku, FI \\ petro.pesonen@utu.fi \\ 2 Laboratory of Chronology, University of Helsinki, Helsinki, FI \\ markku.j.oinonen@helsinki.fi
}

\begin{abstract}
The chronology of the eastern Fennoscandian Neolithic is organized with the help of pottery styles, one of which is southwestern Finnish Jäkärlä Ware. In this paper a number of new radiocarbon dates connected with Jäkärlä Ware and other relevant ceramic groups are presented and discussed. The radiocarbon dates of each group are modelled within a Bayesian chronological framework. Also, the potential reservoir effect in charred crust dates is estimated for each date based on stable carbon isotopic ratios of the crust samples and incorporated into models. Jäkärlä Ware appears to be a short-living and quite a isolated group, which had no chronological contacts with Sperrings 1-2 Wares, but with possible coexistence with Middle Neolithic Typical Comb Ware. Jäkärlä Ware is partly simultaneous with eastern Finnish asbestos-tempered Kaunissaari Ware, and forms with it a short chronological horizon in the turn of the Early and Middle Neolithic of eastern Fennoscandia.
\end{abstract}

KEY WORDS - Bayesian modelling; Early and Middle Neolithic; Eastern Fennoscandia; chronology; radiocarbon dates

\section{Kronologija posod tipa Jäkärlä - Bayesova interpretacija starih in novih radiokarbonskih datumov iz časa zgodnjega in srednjega neolitika na območju JZ Finske}

IZVLEČEK - Neolitska kronologija na območju vzhodne Fenoskandije je organizirana s pomočjo okrasov na lončenini, ene izmed njih so tudi posode tipa Jäkärlä iz območja jugo zahodne Finske. $V$ članku predstavljamo in razpravljamo o številnih novih radiokarbonskih datumih, vezanih na te posode in druge pomembne keramične skupine. Datume vsake od predstavljenih keramičnih skupin smo modelirali z Bayesovim kronološkim okvirjem. Ocenjujemo tudi morebitne efekte rezervoarja na podlagi razmerij stabilnih izotopov ogliika pri datumih, pridobljenih iz zoglenelih organskih ostankov na keramiki, kar smo nato vključili tudi v modeliranje. Posode tipa Jäkärlä kažejo na skupnost, ki je živela izolirano in le kratko časovno obdobje ter ni imela nobenih kronoloških povezav $s$ posodami tipa Sperrings 1-2, opažamo pa določeno sobivanje s srednje neolitskimi posodami z značilnim glavničastim okrasom. Posode tipa Jäkärlä so tudi sočasne s posodami Kaunissaari iz območja vzhodne Finske, ki imajo dodan azbest, in skupaj z njimi sestavlja kratek časovni horizont na prehodu zgodnjega v srednji neolitik na območju vzhodne Fenoskandije.

KLJUČNE BESEDE - Bayesovo modeliranje; zgodnii in srednji neolitik; vzhodna Fenoskandija; kronologija; radiokarbonski datumi 


\section{Introduction}

Jäkärlä Ware, or Jäkärlä pottery, is a special Early Neolithic group of ceramics with a distinctively southwestern Finnish distribution. Traditionally, Jäkärlä Ware has been dated contemporary with the younger style of Early Comb Ware (Sperrings 2 or Ka 1:2) and the beginning of Typical Comb Ware (Ka 2) in Finland. What makes Jäkärlä Ware sites different, e.g., to certain sub-groups within Sperrings 2, is the more differentiated stone tool inventory than in these groups, giving grounds to call Jäkärlä Ware sites a separate group differing from the Early Comb Ware sites.

The chronology of the Jäkärlä group has been a subject of discussion ever since the realization of its typological peculiarity among other comb ceramic groups. First, Jäkärlä Ware was interpreted as a local south-western Finnish variant of Early Comb Ware 1:2, but chronologically belonging to the time of Typical Comb Ware because Jäkärlä Ware was found together with Typical Comb Ware in the Eura Lammila site (Europaeus-Äyräpää 1930.178-179). In the eponymic Turku Jäkärlä site the style is succeeded by Typical Comb Ware, and Europaeus-Äyräpää saw Jäkärlä Ware as a delayed phenomenon of Ka 1:2. This was the state of art formulated in various studies between the 1910s and 1960s before the advent of radiocarbon dating (e.g., Europaeus 1916; 1917; 1922; 1925; 1926; Europaeus-Äyräpää 1930; Riska 1945; Luho 1948; 1952; Meinander 1965; Edgren 1966). A notion put forward especially by Tove Riska (1945) was that in southwestern Finland Jäkärlä ceramics replaced style Ka 2:1 of Typical Comb Ware, rather rare in SW Finland, and was thus succeeded by style Ka 2:2 of Typical Comb Ware.

The first radiocarbon dates of charcoal samples from the Jäkärlä Ware sites were produced at the advent of the methodology in Finland from Sauvo Nummenharju (six pcs) and Eura (Honkilahti) Kolmhaara (five pcs). The Nummenharju datings spanned from 6000 to $5000 \mathrm{BP}$, two Kolmhaara dates were from c. 5450-5400 BP, and the others clearly dating to a later period. Carl F. Meinander, who published the dates, used the median value for Nummenharju, 5625 $\mathrm{BP}$, as a date for Jäkärlä group (Meinander 1971).

The next set of radiocarbon dates from the Jäkärlä context were derived only twenty years later. Seven charcoal samples were dated in 1990 after a smallscale text excavation on the Jäkärlä site Nöjis in
Dragsfjärd (now Kemiönsaari). Curiously enough, these dates are generally younger than the ones from Nummenharju and spanning over 600 radiocarbon years, the median value being $4710 \mathrm{BP}(e . g$., Asplund 1995).

In 1969, Ari Siiriäinen dated the Jäkärlä group according to shoreline chronology into the periods of $\mathrm{Ka} 1: 2$ and Ka 2:1. The dating was not unambiguous, but nevertheless it showed that Jäkärlä Ware would belong to the end period of the Ka 1:2 rather than to its beginning (Siiriäinen 1969.65-66). Later, Siiriäinen pointed out that the radiocarbon dates from Nummenharju are generally too old for the shoreline chronology, showing that the younger limit of the dates is of the age expected while the older limit is at least 500 years more than expected (Siiriäinen 1973.11). In the chronological diagram, Jäkärlä Ware remained an entity without a beginning or an end (Siiriäinen 1973.18). The strong discrepancy between the radiocarbon dates and the shoreline position of the Nummenharju site has been pointed out more recently (Tiitinen 2011.60). In several studies, the problems with the geological shoreline curves for the Southwest Finland have also been put forth (Lehtonen 2005; Asplund 2006; Tiitinen 2011).

The chronological position and the development succession of the Jäkärlä ceramics have been discussed most extensively by Henrik Asplund (e.g., 1990; 1995; 1997; 1998). He maintains the validity of Nummenharju and Nöjis radiocarbon dates, building a line of succession between Ka 1:1 and Pyheensilta Ware, via Jäkärlä Ware. Pyheensilta Ware is a Late Neolithic ceramic group with some common traits and technology with Jäkärlä Ware. Moreover, the connection between Jäkärlä Ware and Uskela Ware (style Ka 3:1 of Late Comb Ware) was proposed earlier (Vikkula 1981.65-67).

With this background of mixed cultural connections and long time span of $c .1500$ years, it is obvious that the dating and also the cultural position of the Jäkärlä Ware is far from clear. In this paper an attempt to give this group a solid chronological background is made and some notes on the cultural affiliations of the group are also presented. The new radiocarbon dates from short-lived materials combined with those from other sources provide us with the possibility to examine the shoreline chronology once more. In this paper the phase chronology of Jäkärlä Ware is established with a Bayesian approach built in the Oxcal calibration programme (Bronk Ramsey 
2009a) that allows for coherent testable quantitative estimates for timing of cultural phases. This same approach is used for other ceramic/cultural groups in the typo-chronological environment in the Early and Middle Neolithic southwestern Finland. Essential ceramic groups in this connection are Sperrings 1 and 2 (Early Comb Ware 1 and 2), Typical Comb Ware and Late Comb Ware.

\section{Early and Middle Neolithic ceramic types in Eastern Fennoscandia}

The earliest Neolithic ceramics in southwestern Finland are called Sperrings Ware or Early Comb Ware. Its origins lie in the Comb-stamp decorated ceramic traditions developed in the northern taiga zone of Eurasia, first appearing $c .6000-5500 \mathrm{cal} \mathrm{BC}$ in the north-eastern part of European Russia (Karmanov et al. 2014), with possible predecessors even further east (Vybornov et al. 2014; Kosinskaya 2014). Sperrings Ware has its ceramic roots in the Upper-Volga area, where it developed and from where it spread to north-western Russia and Finland (Piezonka 2015; Nordqvist 2018). The earlier Sperrings 1 Ware tradition continued in the later Sperrings 2 Ware, which was however limited mainly to Finland, and not to Karelia, where Pit-Comb Ware prevailed after Sperrings 1 ceramics (Nordqvist, Mökkönen 2016). In southwestern Finland the succession of ceramic types and/or cultures continued with Typical Comb Ware and Late Comb Ware, of which Late Comb Ware is a markedly southern/western coast type, while several ceramic types after Typical Comb Ware appeared inland (e.g., Carpelan 1979; Vikkula 1981; Nordqvist 2018).

Some of the prominent sites of the Sperrings 1 Ware (Early Comb Ware 1 or Ka 1:1, Fig. 1a) are known in Southwest Finland, e.g., Kokemäki Kraviojankangas site in Satakunta. It seems that Sperrings 1 Ware does not have chronologically much in common with the Jäkärlä Ware, even though the earliest dates from Sauvo Nummenharju site would fit into this period (e.g., Pesonen et al. 2012). In contrast, Sperrings 2 Ware (Early Comb Ware 2 or Ka 1:2, Fig. 1.b-c) has often been considered as a contemporary phenomenon with the Jäkärlä Ware and these both as later developments following Sperrings 1 Ware. Within this sequence of events, Typical Comb Ware was thought as an interference disturbing the development. However, the people producing Typical Comb Ware and Jäkärlä Ware were speculated to have lived together in the same area for some time (e.g., Meinander 1965; Edgren 1966; Asplund 1995;
1998). This situation of cultural melange makes it interesting to try to find out the chronological niches of these other ceramic groups in southwest Finland during the time.

Sperrings 1 Ware was the earliest type of ceramic in southern Finland, and it spread all the way to southern Lapland and Russian Karelia. Sperrings 1 Ware is roughly contemporaneous with the northern Säräisniemi 1 Ware. These two ceramic styles also have a common distribution in northern Ostrobothnia, southern Lapland and Russian Karelia (e.g., Piezonka 2015). In an earlier study (Pesonen et al. 2012) the chronological boundaries for Sperrings 1 ceramics were defined for the northern and southern part of the eastern Fennoscandia separately. In the southern part of the distribution area Sperrings 1 Ware was dated $c$. 5145-4400 cal BC with the continuation of Sperrings 2 Ware $c$. 4400-4175 cal BC.

Typical Comb Ware (Ka 2; Fig. 1h) succeeded earlier ceramic types in many areas, and did not spread any further north than Sperrings Ware did. Among other things, the more or less common distribution has led to the assumption that there was a continuum from Sperrings to Typical Comb Ware, even though the central cultural attributes within these two ceramic carrying traditions differ a lot. For example, the use of semi-subterranean houses, richly furnished graves and contacts to the amber and flint areas are almost extinct within Sperrings Ware while they are common in Typical Comb Ware sites (e.g., Meinander 1984; Carpelan 1999; Pesonen 2002; Nordqvist, Mökkönen 2015; Mökkönen, Nordqvist 2016).

Late Comb Ware was the third stage in the Äyräpää's succession of comb ceramics. It was first defined as a 'degenerated style' of Typical Comb Ware (Europaeus-Äyräpää 1930.183). Later on, this pejorative denomination was largely rejected and the role of Late Comb Ware and its connections realized (e.g., Vikkula 1981). In particular, a possible stylistic and chronological connection between Jäkärlä and Late Comb Ware has been suggested (e.g., Asplund 1995; 1998).

\section{Jäkärlä Ware and its setting in southwestern Finland}

\section{Jäkärlä Ware characteristics}

Jäkärlä ceramics, i.e. Jäkärlä Ware of the Jäkärlä group, was defined according to ceramics analysed from 22 settlement sites known by 1965 (Edgren 1966). The ceramics are the most important factor 
Fig. 1. Examples of radiocarbon dated ceramics in this study. a Sperrings 1 Ware, Porvoo Böle (KM 17074:724, Hela-3177, $5884 \pm 43$ BP); b Sperrings 2 Ware, Raasepori Timmerkärr (KM 31635:210, Hela-3170, $5614 \pm 41$ BP; c Sperrings 2 Ware, Espoo Kläppkärr (KM 31107:399, Hela-3173, 5439 43 BP); d Jäkärlä Ware, Espoo Mynt (KM 13594:392, Hela3166, 5210 \pm 40 BP); e Jäkärlä Ware, Turku Jäkärlä (KM 8063:107, Hela3169, $5119 \pm 42$ BP); fJäkärlä Ware, Lieto Kukkarkoski II (KM 16879:161, Hela-3176, 5130 40 BP, MRE corre cted $5096 \pm 43$ BP); g inner surface of Jäkärlä Ware, Lieto Merola (KM 16879:28, Hela-3172, 5002 \pm 40 BP, $M R E$ corrected $4992 \pm 40 \mathrm{BP})$; and h Typical Comb Ware, Nousiainen Kukonharja 2 (KM 38207:21, Hela-3178, $4829 \pm 40 \mathrm{BP}$, MRE corrected $4560 \pm$ $137 \mathrm{BP})$.

that constitutes the Jäkärlä group, as no other artefact group or solid structure is present in all sites.
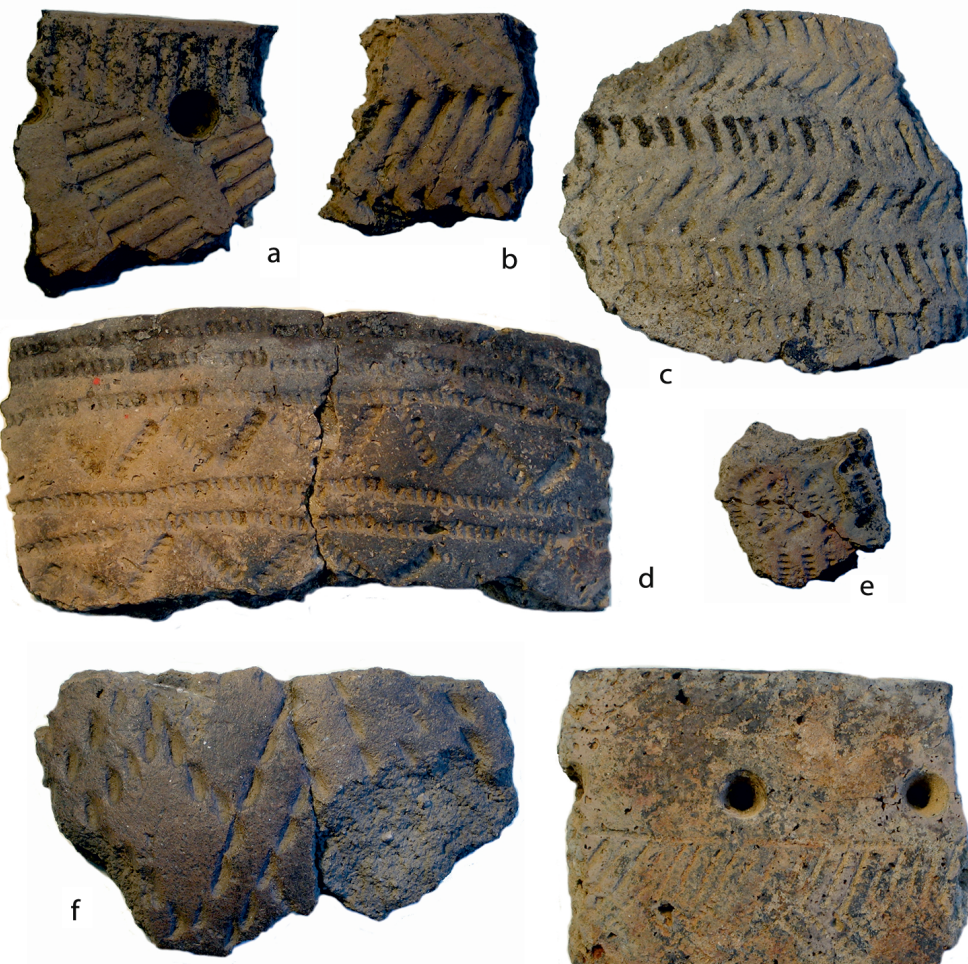

h

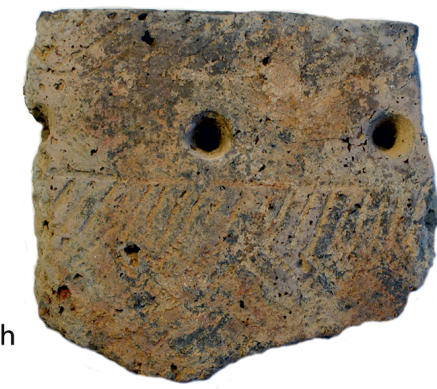

$10 \mathrm{~cm}$
The diatom poor clay used in Jäkärlä ceramics is of glacial origin. Such clay deposits are available in the surroundings of many Jäkärlä sites. Jäkärlä ceramic sherds are often very porous, which points to the use of organic substances in tempering. These materials have obviously been dissolved during the taphonomic process in the ground. In some sherds, however, survived pieces of Cardium-shells have been detected among temper material. The firing of Jäkärlä pots presumably happened at a relatively low temperature as the sherds are often grey. Sometimes the surface of the wall has been split away, and this indicates the use of an extra clay slip on the surface (Edgren 1966.107-109). The technological choices are different from the other Early Neolithic potteries, where, for example, Sperrings 1-2 pots are often tempered with rock minerals.

The forms of the vessels follow the standard comb ceramic forms, where the most common type is a round-bottomed, unprofiled large jar. Sometimes the rim-part is bent a little inwards. A few occurrences of flat-bottomed jars exist, and some small, low bowllike vessels and miniature vessels also occur ( $E d$ gren 1966.109; 1983).

The decoration of Jäkärlä pots covers the whole vessel body, but the rim top decoration occurs very ra- rely. This is also a common trait in Sperrings 1-2 Wares and Säräisniemi 1 Ware of northern Finland, while in other later or contemporary ceramics Early Asbestos Ware and Typical Comb Ware rim top decoration is dominant. The most common decoration stamps are comb stamps, twisted cord stamps, tube stamps and oval or grain-shaped stamps (e.g., Fig. 1.d-f). The comb stamps are most common, and they are usually oval-shaped and relatively wide. The decoration is overall horizontal (Edgren 1966.110111).

The most distinct peculiarities of Jäkärlä Ware compared to roughly contemporaneous and geographically overlapping ceramic styles (Typical Comb Ware, Sperrings Ware 1-2) are the organic temper material, poorly fired clay (grey in colour), the use of broad and oval comb stamps, and the absence of pit stamps and the rim top decoration. These features make it possible to distinguish Jäkärlä Ware from other ceramic styles in the find material.

However, the typological difference between Jäkärlä Ware and Sperrings 2 Ware is sometimes very difficult to decipher. The use of organic temper is not a rare occurrence in Sperrings 2 Ware, either. Sometimes, only the decoration with broad and oval stamps in Jäkärlä Ware separates it from Sperrings 
2 Ware, which is usually decorated with long comb stamps or lines (Rankama 1982).

\section{The geographical distribution and natural environment of Jäkärlä Ware sites}

Judging by its distribution, Jäkärlä ceramics are a characteristically southwestern Finnish phenomenon. Of the $c .50$ sites, $^{1}$ a vast majority are situated in the southwestern provinces of Varsinais-Suomi and Satakunta (Fig. 2). A number of sites are also spread along the southern coast of Uusimaa and Kymenlaakso, and the most eastern site is situated in Virolahti, near the Russian border. There are two sites on the Åland Islands and a few sites in the provinces of South and North Ostrobothnia, the northernmost site lies in Kalajoki, in North Ostrobothnia. Due to the rebounding of the earth's crust after the Ice Age, the sites are today in the inland, but all the evidence points to the fact that they were without exception once maritime and coastal sites.

In the Middle Holocene, during the Jäkärlä period, the climate was optimal and this contributed to increased productivity and greater availability of natural resources. The forests were composed mainly of pine and broad-leaved trees, with water chestnut thriving in small ponds, etc. (e.g., Tallavaara 2015. 48-49; Tallavaara, Seppä 2012). The Jäkärlä sites were situated at the coast, near to both maritime and terrestrial resources (e.g., Tiitinen 2011). The lipid analyses conducted recently on Jäkärlä ceramics also show the use of both resources (Papakosta, Pesonen 2019; Pääkkönen et al. 2016).

The Jäkärlä pottery was obviously used for cooking both terrestrial and aquatic products. So far there have been no osteological analyses connected directly with Jäkärlä Ware. In the eponymous Turku Jäkärlä site, seal and fish dominate, but the osteologial material is limited and the context is mixed (Pääkkönen et al. 2016.70). The aquatic/maritime orientation of the Jäkärlä group and its ceramics must be kept in mind. The radiocarbon dates conducted on the Jäkärlä pottery food crust are thus vulnerable to the marine reservoir effect (see later).

Pure contexts of Jäkärlä Ware are rare. For a long time only the Sauvo Nummenharju site was known, but later other sites with only Jäkärlä ceramics were discovered, e.g., Kemiönsaari Nöjis (Asplund 1990; 1995). But from the chronological point of view, the mixed sites also tell stories. In Finnish coastal con- ditions, the mixing of chronologically different cultural items principally happens only during a fairly limited time period, when the shoreline was still close enough to the settlement site. The mixing thus gives a chronological hint for the dating of Jäkärlä Ware. Of the $c .50$ sites with Jäkärlä ceramics, two are mixed with Sperrings 1 Ware, ten with Sperrings 2 Ware and 20 with Typical Comb Ware. Late Comb Ware (aka. Uskela ceramics) occurs in eight sites together with Jäkärlä Ware, Corded Ware at 11 sites and Pyheensilta Ware at six sites. Bronze Age and Iron Age ceramics are also featured in some sites. It thus seems that Jäkärlä Ware would have a common geographical contact mainly with Sperrings 2 Ware and Typical Comb Ware.

\section{Material and methods}

\section{Radiocarbon dating procedures}

For this paper, 18 samples from charred crust of ceramics and burnt bone were radiocarbon dated (eight samples of Jäkärlä Ware, two samples of Sperrings 1 Ware, four samples of Sperrings 2 Ware and four samples of Typical Comb Ware). The chemical pretreatment protocol for the charred crust samples followed an acid-alkali-acid (AAA) treatment (Taylor, Bar-Yosef 2014.93). The protocol for burnt bones was according to Dorien Lanting et al. (2001). The pre-treated samples were converted to $\mathrm{CO}_{2}$ either by combusting (charred crusts) or acid release (burnt bones) after which the $\mathrm{CO}_{2}$ samples were converted to graphite targets (Slota et al. 1986) by chemical reduction. The AMS radiocarbon measurements were carried out by the Uppsala Tandem Laboratory (Possnert 1984) on these graphite targets. All conversions to calendar years were performed using the Oxcal software (Bronk-Ramsey 2009a) and with the Intcal13 radiocarbon calibration curve (Reimer et al. 2013).

\section{The data selection}

Additional radiocarbon dates were gathered from the database collected during the Argeopop-project (Pesonen, Sundell 2011) and most of these have already been published in several papers (e.g., Pesonen et al. 2012; Oinonen et al. 2014). The original dates are reproduced in Appendices (1-2). Even though Jäkärlä Ware is the focus of this paper, it is necessary to also deal with the other ceramic groups relevant in this connection, which are Sperrings 1 Ware, Sperrings 2 Ware, Typical Comb Ware and Late Comb Ware. The Sperrings 1-2 and Late Comb

1 The exact number of sites is not fixed, as the identification of Jäkärlä Ware in some sites remains uncertain. 
Ware dates are so far so few that only Typical Comb Ware could be studied separately for southwestern Finland, with regard to the main distribution area of Jäkärlä Ware. Sperrings 1-2 Wares and Late Comb Ware were studied for the whole area of Finland.

There are currently 69 radiocarbon dates available from sites where Jäkärlä Ware has also been disco- vered (Appendix 1 at http://dx.doi.org/10.4312/dp. 46.15). Inevitably, many of these sites are multiperiodic, and thus a large proportion of the radiocarbon dates lack a proper context. Altogether 31 dates from 11 archaeological sites were deduced to be in close contact with the Jäkärlä pottery ('class 2' dates; see later). Of these, ten dates are charred crust from the pottery surface, one is a burnt bone date, one is

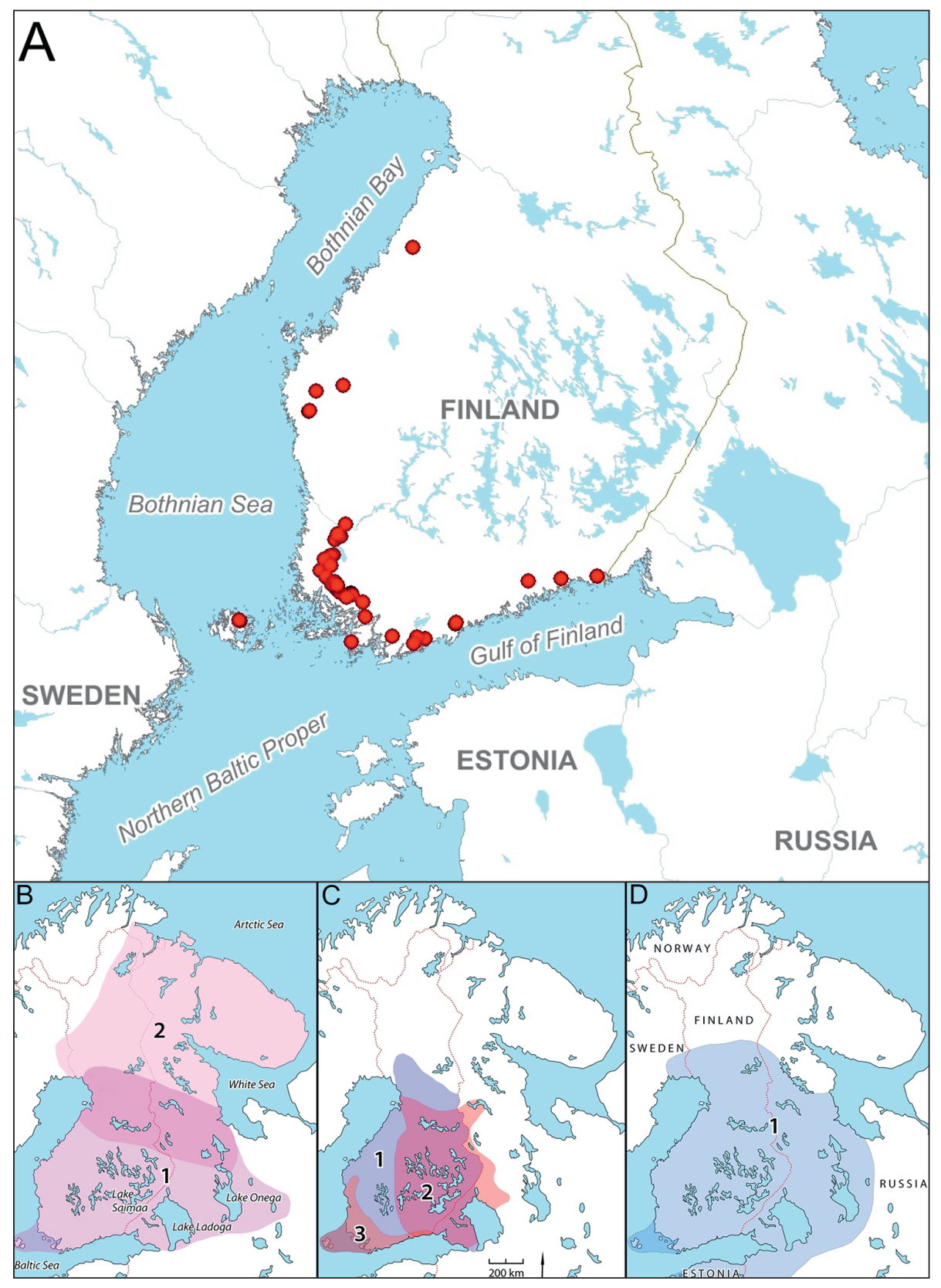

Fig. 2. Early and Middle Neolithic ceramics in Finland. A The distribution of Jäkärlä Ware in the former coast of the Baltic Sea. The list of sites is in Appendix 3 at http://dx.doi.org/10.4312/dp.46.15; B The first half of the Early Neolithic. 1 Sperrings 1 Ware; 2 Säräisniemi 1 Ware; C The second half of Early Neolithic. 1 Sperrings 2 Ware; 2 Asbestos-tempered Sperrings 2 and Kaunissaari Wares; 3 Jäkärlä Ware; D Early Middle Neolithic. 1 Typical Comb Ware. The distribution of the Late Comb Ware (Uskela Ware) coincides roughly with that of Jäkärlä Ware, though several variants of Late Comb Ware are present also in the Finnish inland and Baltic States (e.g., Nordqvist 2018). Maps B-D from Nordqvist, Mökkönen 2017, published with a permission from the authors. Original design of maps B-D by Kerkko Nordqvist, modified by Petro Pesonen. 
a charred nut date and the rest are traditional charcoal dates. Most of the charred crust dates and the single burnt bone dating were performed for this paper, with the exception of one crust date from the Turku Jäkärlä site (Pääkkönen et al. 2016) and two crust dates from the Nousiainen Kukonharju 2 site made earlier (unpublished). ${ }^{2}$ Most of the charcoal dates have already been published (Meinander 1971; Asplund 1995), but one date from the Turku Jäkärlä site has been published only in the date list and in the related open-access database (Junno et al. 2015). Three dates from the Nousiainen Rauannniittu site and three dates from the Eura Kolmhaara site have not been published before. 3

For the other periods similar screening of dates was applied, even though it is sometimes difficult for the samples from multiperiod sites. For the Sperrings 1 and 2 Wares, those dates sampled from gyttja layers or having unknown origin were left out altogether. The same applies in principle also to the Typical and Late Comb Ware dates.

Because the charcoal dates typically have much larger error margins and also because of potential error sources in the samples themselves, the calibration runs were performed for each period also just on charred crust and birch bark dates. Luckily, the corpus of crust and birch bark tar dates has gradually grown, so these kind of general, phasewise dating schemes are now possible to make. Altogether 350 dates were applied in this study (Jäkärlä dates included in the count), and of these 152 are charred crust and birch bark tar dates (see Appendix 2 at http://dx.doi.org/10.4312/dp.46.15). As for the Jäkärlä dates, most of these have also been published earlier in various papers and in the open-access database (www.oasisnorth.org/14carhu), but some are published for the first time in this paper with the permission of the original samplers.

\section{Radiocarbon dates in Jäkärlä Ware context}

Charcoal dates from Jäkärlä sites have a wide chronological variation spanning from $5990 \pm 180 \mathrm{BP}$ (Hel-48) to $4490 \pm 120$ BP (Hel-2816), while more reliable charred crust dates show a much shorter timeslice for the ceramics from $5230 \pm 41$ BP (Hela-2660) to $5055 \pm 41 \mathrm{BP}$ (Hela-3076). One charred crust date (7450 \pm 49 BP; Hela-3075) is over 2000 radiocarbon years older than the other crust dates and $2400 \mathrm{ra}-$ diocarbon years older than the other charred crust dating from the same site (5055 $441 \mathrm{BP}$; Hela-3076). It turned out, however, that there was probably some glue or conservation liquid in the dated sherd (glued together from two pieces), which may have contaminated the result as the glue was probably made of fossil (i.e. old radiocarbon-free) material, and was thus likely resistant against the chemical pretreatment. When calibrated, the mean result is $6325 \pm 55$ cal BC, ${ }^{4}$ which is more than 1000 years older than any ceramic date from Finland and neighbouring areas. This date is thus rejected as potentially contaminated. The other charred crust dates seem to be reliable as far as it is possible to judge from the successful analysis procedure and results.

The charcoal datings of Jäkärlä Ware are problematic, as 1500 radiocarbon years for an otherwise very local and even an 'introvert' cultural feature seems to be an unexpectedly long time period. In the following, the reliability of the each charcoal series is discussed.

According to shoreline chronology, the older end of the Sauvo Nummenharju dating series seem in particular to be anomalously old (Siiriäinen 1973.11). Siiriäinen observed, that "it may be a question of the excessive dispersion which has been generally observed in datings obtained from the hearth charcoal of settlements" (Siiriäinen 1973.11 with references). Nummenharju remains an enigmatic site, as the context of the samples seems to be fairly good. One further reason to suspect the charcoal dates of the site is however a new burnt bone result from the area (Hela-3165; 4926 \pm 35 ), which is $c .100$ radiocarbon years younger than any of the charcoal dates from the site and it obviously fits fairly well also in the shoreline chronology (cf. Tiitinen 2011). However, the $\delta 13 \mathrm{C}$-value of the burnt bone is considerably higher than any other values in the data set, $-12.7 \%$. This resembles a highly marine value, and probably shows the conservation of the marine signal in the sample despite the burning process (see discussion on the burnt bone dates below).

In contrast, the dating series from the Kemionsaari Nöjis site is from the lower end of the whole sequence, with a span of $c .600$ radiocarbon years.

2 The dates from Nousiainen Kukonharju 2 were initiated by Simo Vanhatalo, Finnish Heritage Agency (Vanhatalo 2010).

3 The dates from Nousiainen Rauanniittu were initiated by Simo Vanhatalo (Vanhatalo 1991), and the dating from Eura Kolmhaara by Päivi Kankkunen, of the Finnish Heritage Agency (Kankkunen 2005).

4 In this paper, all calibrations are made with Oxcal v. 4 or later (Bronk Ramsey 2009a) and the atmospheric data is from Reimer et al. (2013). 


\begin{tabular}{|c|c|c|c|c|c|c|c|c|c|}
\hline & $\begin{array}{c}\text { charred } \\
\text { crust }\end{array}$ & $\begin{array}{c}\text { birch } \\
\text { bark tar }\end{array}$ & $\begin{array}{l}\text { black } \\
\text { paint }\end{array}$ & $\begin{array}{c}\text { chewing } \\
\text { resin }\end{array}$ & $\begin{array}{l}\text { burnt } \\
\text { bone }\end{array}$ & $\begin{array}{l}\text { charred } \\
\text { nut shell }\end{array}$ & charcoal & wood & altogether \\
\hline Sperrings 1 & 35 & 5 & 1 & & 8 & & 33 & & 82 \\
\hline Sperrings 2 & 18 & & & & & & 8 & & 26 \\
\hline Jäkärlä (class 1 and 2) & 10 & & & & 1 & 1 & 19 & & 31 \\
\hline Typical Comb Ware & 24 & 48 & & 13 & 12 & 2 & 84 & 5 & 188 \\
\hline Late Comb Ware & 9 & 3 & & & 1 & 2 & 8 & & 23 \\
\hline altogether & 96 & 56 & 1 & 13 & 22 & 5 & 152 & 5 & 350 \\
\hline
\end{tabular}

Tab. 1. The radiocarbon dates and sample material in each ceramic group.

There is no clear information how the Nöjis dates were obtained, but by the nature of the excavation (test pitting) it is reasonable to suspect they are charcoal pieces collected from the cultural layer, which are not very reliable in normal circumstances as they may as well derive from forest fires and the like. However, most of the Nöjis datings are in fairly good accordance with the shoreline chronology.

One of the oldest datings in the Jäkärlä series is a

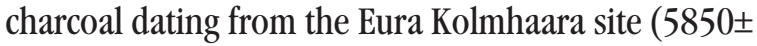
90; Hel-4612). There are many other dates, but they are usually thought to belong to the Typical Comb Ware phase of the site. However, it is noteworthy, that there are also two quite early Typical Comb Ware context dates which were also dated in the same era as the above-mentioned Sauvo Nummen-

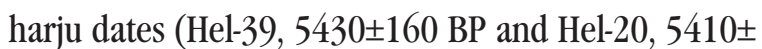
$150 \mathrm{BP}$ ). These are 250 radiocarbon years older than the oldest charred crust Typical Comb Ware date from Kolmhaara (Hela-362; 5155 $\pm 60 \mathrm{BP}$ ), which itself is almost 400 radiocarbon years older than two AMS-dates from charcoal and charred nut from the site (Hela-651, 4775 $\pm 65 \mathrm{BP}$ and Hela-650, 4710 $55 \mathrm{BP}$ ), which are from the Munasaari part of the site, interpreted primarily as a Jäkärlä group part in the Kolmhaara site. There thus seems to be a pattern which gives older dates for those radiocarbon dates conducted in the early years of radiocarbon dating in Finland, but also a pattern which gives old dates for the charcoal samples in the region in general when using the conventional dating method. It is however obvious that, judging from the Kolmhaara dates alone, the Jäkärlä and Typical Comb Ware are contemporaneous phenomena. According to the excavation report, the above-mentioned old date Hel-4612 is from a fireplace stratigraphically below the other fireplaces in the site, which were dated to the Jäkärlä period (Kankkunen 2005) giving grounds for rejecting this date from the Jäkärlä context. The other two dates (Hela-650 and Hela-651) are from the same excavation and are interpreted to derive from a Jäkärlä context. However, these two dates are considerably younger than the other dates of the site and other dates with Jäkärlä contexts elsewhere. Thus a doubt arises as to whether they truly represent Jäkärlä Ware.

The Nousiainen Rauanniittu site might be a pure Jäkärlä group site, or at least no other ceramic types have been found in the site so far. The site was test excavated in 1988 (Vanhatalo 1991). The excavation is well documented and the radiocarbon dates seem to be from reliable contexts in the fireplaces. The importance of the site is further attested by the presence of a potential pithouse in the site, which is unique if truly assigned to the Jäkärlä group. Apart from two charred crust dates, one charcoal date from the Turku Jäkärlä site also exists. This was collected in 1985, but on the basis of the excavation report alone (Salo, Laukkanen 1986) the context of the date is impossible to define, so this date is eventually rejected.

After such scrutiny only 15 dates were thought reliable enough, and most probably connected with the Jäkärlä Ware (class 1 dates). However, it is useful to make runs also with all 31 dates (class 2 dates) in order to see how great an effect the new dates really have on the dating of the whole cultural group.

\section{Radiocarbon dates in Sperrings 1-2 Ware, Typical Comb Ware and Late Comb Ware con- texts}

Sperrings 1 and 2 Wares are also present in the Karelian Republic and Leningrad oblast in Russia (German 2009; Nordqvist, Mökkönen 2016). A number of radiocarbon dates also derive from this region and these were used in this study too. Altogether 82 radiocarbon dates are from the Sperrings 1 context and 26 from the Sperrings 2 context. Five Sperrings 1 Ware dates and six Sperrings 2 Ware dates are published for the first time in this study, and six of these samples were dated by the authors for this work. The seven oldest radiocarbon dates are from Sperrings 1 contexts in the Karelian Republic and Leningrad oblast, and six of these are from charcoal samples and one from a burnt bone sample 
(e.g., Piezonka 2008; German 2009; Nordqvist, Mökkönen 2016). The burnt bone from Sulgu 2 site is the oldest of all, $6670 \pm 35 \mathrm{BP}$ (KIA-35900), but it may well derive from settlement use in Mesolithic times (Piezonka 2008). The oldest context date from Finland is from a burnt bone sample in the Erolan-

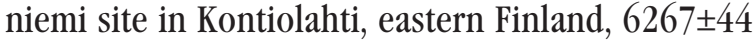
$\mathrm{BP}$ (Hela-2557), and the oldest charred crust date is from the Uja III site in the Karelian Republic, Russia, dated to $6225 \pm 40$ BP (GrA-63566; Nordqvist, Mökkönen 2016).

The contact period between Sperrings 1 and 2 Wares has previously been studied with the help of Bayesian modelling with a two-phase model, and the boundary between successive phases was estimated to be $c$. $4400 \mathrm{cal} \mathrm{BC}$ (Pesonen et al. 2012). There is a group of radiocarbon dates younger than this limit in the Sperrings 1 context, and a number of dates older than this in the Sperrings 2 context. The youngest date within the Sperrings 1 context is from the Haasiinniemi site in Lieksa, eastern Finland, dated to 5240 $110 \mathrm{BP}$ (Hel-3574), and oldest date within the Sperrings 2 context is from the Kivimäki site in Pielavesi, central Finland, dated to $5680 \pm 40$ BP (GrA-62077). Thus major overlap may occur for several reasons: 1) a true, slow shift of styles, 2) problems in defining the ceramic styles, and 3) problems in specifying the context of the sample.

Sperrings 2 dates are not as numerous as Sperrings 1 , but there are now enough of them to form a picture of its chronological framework. The youngest Sperrings 2 dates are clearly overlapping with the Typical Comb Ware dates, but it is noteworthy that none of the direct datings (charred crust and birch bark tar) overlap, as the youngest Sperrings 2 charred crust is from the Summassaari Uimaranta site in central Finland and dated to $5335 \pm 45$ BP (Hela-642), while the oldest Typical Comb Ware charred crust is from the Törmävaara site in northern Finland and dated to $5160 \pm 100 \mathrm{BP}$ (Hela-78).

Typical Comb Ware is present in great numbers also in northwest Russia, the Baltic states and to some extent also in Sweden. Accordingly, a number of radiocarbon dates exist also from these regions, but for the purpose of this study only some samples from Leningrad oblast and the Karelian Republic were taken along in the study, as there are many Typical Comb Ware contexts and direct dates from Finland and a few more would not add much to the corpus. As already noted, a number of early Typical Comb Ware contexts dates are available, with the earliest example from the Autioniemi site in Hankasalmi and dated to $5500 \pm 170 \mathrm{BP}(\mathrm{Hel}-30)$. It was noted already at the end of the 1990s that the early dates derived from charcoal are in strong conflict with the birch bark tar and the charred crust dates (Pesonen 1999), and this remains the case. The earliest set of Typical Comb Ware context dates are likely outliers.

The youngest Typical Comb Ware date is from a multiperiod site of Naarajärvi in Pieksämäki, central Finland, dated to $4200 \pm 190 \mathrm{BP}$ (Hel-1926), and there are a number of other dates almost as young as this. There is again a strong overlap between Typical Comb Ware and Late Comb Ware dates, as the oldest Late Comb Ware date from the Maarinkunnas site in Vantaa, southern Finland, is $4940 \pm 70$ BP (Hela-259). The overlap is significant and really comprises the younger part of the whole Typical Comb Ware sequence of dates. The problems in direct seriation of these two ceramic types have already been noted (Leskinen 2003; Räihälä 1996). This overlap may have similar causes as the overlap between Sperrings 1 and 2 dates. Late Comb Ware is here understood predominantly as Uskela Ware (as defined by Vikkula 1981), because the late forms of Comb Ware and their connection with the other Middle Neolithic ceramic types (e.g., Kierikki, Zalavruga, Orovnavolok and Voynavolok Wares) are not fully understood and studied in the Finnish assemblages (Mökkönen, Nordqvist 2018). The distribution of Late Comb Ware (of the Uskela-type) is extended to the Karelian Isthmus (Kholkina 2018), but obviously it is mainly a coastal type with other ceramic types dominating in inland Finland during the Late Middle Neolithic. The youngest Late Comb Ware context date is from the Ostrobothnia, Bläckisåsen site in Kokkola, and dated to $4200 \pm 60 \mathrm{BP}$ (Su-1568), i.e. to the same time as the youngest Typical Comb Ware context date from Naarajärvi in Pieksämäki (see above).

\section{Reservoir effect and other potential error sour- ces}

There are many potential error sources affecting the radiocarbon dating results. Besides the obvious potential error sources in sampling, which indeed is one of the most crucial points in the radiocarbon dating procedure, some other error sources in the dated material itself are also a risk. One of the most challenging ones is the so-called reservoir effect. Radiocarbon dating is based on comparison of the measured radiocarbon content of a sample to the known past atmospheric radiocarbon contents. If all the carbon in aquatic environments would be based on just dissolved atmospheric carbon dioxide into water, 
the radiocarbon content of the aquatic and atmospheric carbon would resemble each other. However, aquatic organisms, marine in particular, contain typically less radiocarbon compared to contemporaneously-living terrestrial organisms due to old dissolved organic carbon in water, to the slower aquatic carbon cycle and to dissolved inorganic carbon from limestone bedrocks. These result in older values for the dates than expected if aquatic carbon is involved.

The amount of marine reservoir effect (MRE) within the Baltic Sea varies according to the assumed geographical origin of carbon from $c .400$ radiocarbon years at the Danish Straits to $c$. 25-50 radiocarbon years at the bottom of the Bothnian Bay (Lougheed et al. 2013). In the marine conditions of the northern Baltic Sea (between $59^{\circ}$ and $66^{\circ} \mathrm{N}$ latitude), the current average value of the MRE is estimated as $231 \pm 113$ radiocarbon years $(\mathrm{N}=8$, CHRONO Marine database, http://calib.org/marine/; Appendix 4 at http://dx.doi.org/10.4312/dp.46.15).5 One possibility to estimate this systematic offset is to make a correction based on the stable isotope signals $\left(\delta^{13} \mathrm{C}\right.$ and $\delta^{15} \mathrm{~N}$ ) in the dated material. The isotopic ratios reflect the marine or terrestrial origin of the food ingredients present in the crust sample, and it is possible to scale down the maximal reservoir effect in each sample based on this data (Pesonen et al. 2012; Oinonen et al. 2013a).

The ${ }^{13 \mathrm{C}}$ values of the eight Jäkärlä charred crust dates vary between -27.1 and $-19.5 \% .6$ These values are in line with the other charred crust values obtained in Finland (Pesonen et al. 2012.665). Generally, the average value for terrestrial samples in the food residue is about -26\% (Fischer, Heinemeier 2003.460-461; Pesonen et al. 2012). As the Jäkärlä sites have been considered to situate at the marine shoreline, it is assumed that aquatic influence is essentially also marine, and thus any potential freshwater influence would be minimal. Four of the charred crust dates have values over $-26 \%$, but only the samples from the Nousiainen Kukonharju 2 site have a clear marine signature $(-19.5$ and $-20.8 \%$ o) and the potential of the reservoir effect must thus be considered. Interestingly, another one of these Kukonharju 2 dates is the oldest crust date of Jäkärlä Ware. The reservoir effect correction with the procedure explained in Pesonen et al. (2012) has been applied, and corrected values for the four Jäkärlä crust dates used in the model runs.

To perform comparable chronological analysis to our previous work, Pesonen et al. (2012), we have adopted $\delta^{13} \mathrm{C}=-19.3 \pm 2.0 \%$ as the $100 \%$ marine isotopic signature. The isotopic baseline values for the Bothnian Sea and Bothnian Bay are different for marine animals on both sides of the Quark (a strait between Bothnian Bay and Bothnian Sea). This means that for correction of the reservoir effect, in addition to the different maximal MRE, different isotopic values should also be used for maximal $100 \%$ marine share in the correction procedure for different parts of the Baltic Sea. Obviously, these would slightly affect the outcome of the reservoir correction procedure. The maximally terrestrial $\delta^{13} \mathrm{C}$ value $(-26 \pm 1 \%$ ) is based on measurements on terrestrial material and is robust (e.g., Fischer, Heinemeier 2003; Pesonen et al. 2012.665-660). A sensitivity analysis has been made by assuming a $\delta 13 \mathrm{C}$ value of $-15.9 \pm 2.0 \%$ as representing the $100 \%$ marine content in the crust. The value is derived from an open access database (www.oasisnorth.org/diana; Etu-Sihvola et al. 2019). The isotopic signature for the flesh of the marine animals was deduced as $\delta^{13} \mathrm{C}=-15.9$ $\pm 1.8 \%$ o for the areas south of the Quark (lat. 56$63^{\circ} \mathrm{N}$ ) based on bone collagen data and by assuming a collagen - flesh isotopic offset of -1\% (Fernandes 2016). The results of the sensitivity analysis show only minor effects in the modelled boundary values. The maximum effect observed is 95 years for the start boundary of the Late Comb Ware crust and birch bark tar dates, obviously caused by several very high marine signals in crust samples. This makes the individual corrected dates and corresponding model result slightly younger when the alternative $100 \%$ marine isotopic value is adopted. For all the other boundaries, the changes due to this alternative selection were within the original uncertainty estimates. Although an extensive pairwise marine terrestrial sample comparison approach could also cross check our results in the future (e.g., Edinborough et al. 2016), this is well beyond the scope of the present study. In the meantime, we conclude that the modelling results, except for Late Comb Ware, are not significantly affected by the assumed isotopic signature for a $100 \%$ marine crust. We also note that this kind of approach is crucial to improving the analysis procedure.

5 In Pesonen et al. (2012) the MRE was defined as $279 \pm 77$ years according to values then available from the whole Baltic Sea basin. Now it was possible to choose only the eight northernmost datapoints that better refer to Finnish conditions, thanks to new measurements by Lougheed et al. (2013). The Northern Baltic Sea data is from studies by Olsson (1980) and Lougheed et al. (2013).

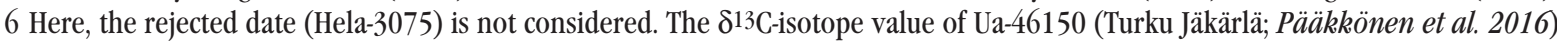
has not been reported. 
Although bone is prone to a confounding reservoir effect through the food chain, there is a strong possibility that burnt (or cremated) bone dates actually represent the age of the wood burned in the pyre (Hüls et al. 2010; Van Strydonck et al. 2010; Olsen et al. 2012). In fact, the original study by Lanting (2001) compared burnt bone dates to charcoal dates from the same contexts. If the carbon of the inorganic component of burnt bones is replaced by charcoal carbon, then the radiocarbon measurements of the samples would still be coeval. Thus, burnt bone dates should have the same potential errors as traditional charcoal dates, which in principle should not carry any other error sources except the possible old wood effect. At the same time, the replacement of the animal carbon signal by the wood carbon signal would eliminate the possible reservoir effect in the burnt bone dates. No burnt bone radiocarbon dates have thus been corrected for the reservoir effect in this paper.

\section{Bayesian modelling of the archaeological dates}

Bayesian modelling of radiocarbon dates was pioneered in Britain during the 1990s and 2000s (e.g., Buck et al. 1991; Bayliss 2009; 2015; Bronk Ramsey 2009a) and in Scandinavia (e.g., Edinborough 2009), and modelling of a series of dates has become a standard procedure in many archaeological projects. Such modelling, with archaeological a priori considerations on the order, is especially useful in stratigraphic contexts (e.g., Oinonen et al. 2013b). Archaeological phases, technological traits, fashions and 'cultures' can be understood as stratigraphic units as well, and these phases and the underlying assumptions can be scrutinized and tested with new Bayesian approaches (e.g., Edinborough et al. 2015). This was also the presupposition in several earlier works, where Säräisniemi 1, Sperrings 1-2, Early Asbestos Ware and Typical Comb Ware phases were discussed and the dates of these modelled (Pesonen et al. 2012; Oinonen et al. 2014). Moreover, analysing dates within a consistent Bayesian framework allows for building comparable time spectra of archaeological events, such as the beginnings and ends of cultural phases, and to study their temporal relations.

In the earlier studies, the models were created with Oxcal software (Bronk Ramsey 2009a), which has extensive built-in capabilities for creating and running models with different parameters. Oxcal is the most widely used programme for Bayesian modelling in archaeology (Bayliss 2015). The current online version Oxcal 4.3 was selected for this study, and a simple model with end and start boundaries (Boundary-command in Oxcal language) was used for each ceramic phase (cf. Edinborough 2009). Outlier analysis (Bronk Ramsey 2009b) was employed in the early stages of the project to recognize those outliers which were not obvious even from the start. ${ }^{7}$ Eventually only one date, Hela-3075 (see above), was hand-picked and removed from the models.

\section{Results}

The results of the runs are presented in Table 2 and Figures 3-4. With the Jäkärlä Ware, the 15 samples classified as class 1 were treated first and they gave mean value limits for Jäkärlä Ware from $4055 \pm 50$ cal BC (start) to $3550 \pm 65$ cal BC (end). With all 31 dates (class 2), the time scale is considerably broader, $c$. 4700-3350 cal BC. Here the Sauvo Nummenharju dates and the earliest Eura Kolmhaara dates are the ones pulling the start boundary earlier. The Nummenharju dates are certainly problematic, as the oldest date is $c .4900 \mathrm{cal} \mathrm{BC}$ (Hel 48; 5990 \pm 180 $\mathrm{BP})$, when the water level of the Baltic Sea was still several meters above the site (e.g., Siiriäinen 1973; Eronen et al. 2001.28 Fig. 7; Hatakka, Glückert 2000). The lower end of Jäkärlä model is dictated by two earlier mentioned dates from the Eura Kolmhaara Munasaari site, obtained in the 2005 excavation (Hela-650 and Hela-651). The reservoir correction of the four 'marine' charred crust dates does not change the model results much. First of all, the amount is small, and even though single dates may contain even 200 years individual MRE correction, their effect on the model result depends on their temporal position within the phase. Moreover, by having larger uncertainties the corrected dates result in wider and more evenly spread calendar-year probability distributions.

The Jäkärlä run was also performed for the charred crust datings only (with the anomalous Mynämäki Aisti crust date Hela-3075 left out), and these mean values give $4035 \pm 40 \mathrm{cal} \mathrm{BC}$ to $3885 \pm 55 \mathrm{cal} \mathrm{BC}$. With the reservoir correction the values are almost same, only the end date going a little later, $3830 \pm 80 \mathrm{cal}$ $\mathrm{BC}$. These values are very interesting and are discussed below. This is perhaps the 'safest' core phase

7 There are a number of radiocarbon dates from Typical Comb Ware sites, that probably reflect later occupation phases at the site. These dates are not used in the runs, nor are they presented in Appendix 2 at http://dx.doi.org/10.4312/dp.46.15 
dating for the Jäkärlä ceramics sequence, i.e. 40303830 cal BC.

A similar procedure was also performed for the other Early and Early Middle Neolithic ceramic groups in Finland. In recent years, new radiocarbon dates have been accumulated and the situation has greatly improved, especially in the case of Sperrings 1 and 2 ceramics, while the already large amount of Typical Comb Ware dates has been growing even more extensive. Only Late Comb Ware does not have so many new dates.

The Sperrings 1 phase dating has a significant difference when one uses the whole dataset with context dates compared to charred crust and birch bark tar dates. The mean boundaries for the whole dataset with MRE correction from $5560 \pm 40$ to $4170 \pm 45$ cal $\mathrm{BC}$, while crust and birch bark dates give from $5155 \pm 50$ to $4335 \pm 50 \mathrm{cal} \mathrm{BC}$. A number of Sperrings 1 charcoal dates from northwest Russia skew the start boundary to Mesolithic times, while a group of charcoal dates from Finnish sites are younger than the youngest Sperrings 1 crust date from the Timmerkärr site in Raasepori, southern Finland (Hela-3175, 5451 \pm $44 \mathrm{BP}$ ). Ten of the charred crust dates show marine inference by their carbon stable isotope values and were corrected accordingly. On the basis of the charred crust and birch bark tar dates, we give Sperrings 1 a phase dating of $c$. 5155-4335 cal BC.

With Sperrings 2 dates the basis for the analysis is not so strong, only 27 dates are connected with the style in Finland and Karelian Isthmus. However, in this case, accounting for the small number of context dates, there is no great discrepancy between the dates from whole dataset and crust and birch bark tar dates. The run with all dates gives us mean value boundaries (with reservoir correction of five charred crust dates) of $4525 \pm 40$ and $4050 \pm 110$ cal BC, while the crust and birch bark tar run results in $4510 \pm 40$ to $4225 \pm 50 \mathrm{cal} \mathrm{BC}$. The latter, fairly concise and short phase, is based on 19 dates, which gives the dating of the phase $c$. 4510-4225 cal BC.

The Typical Comb Ware run is based on total of 183 radiocarbon dates, mostly from Finland, but some also from northwest Russia. The large corpus gives more reliability to the model, where the whole dataset with reservoir correction gives mean values between $3920 \pm 30$ and $3345 \pm 45 \mathrm{cal} \mathrm{BC}$, while 70 dates on crust and birch bark tar values are $3800 \pm 25$ to
$3545 \pm 30$ cal BC. As there are so many radiocarbon dates connected with Typical Comb Ware, it was possible to also make a test run for the Southwest Finnish Typical Comb Ware separately. 8 The results give a slightly shorter phase to the whole dataset, $3900 \pm 60$ to $3445 \pm 85$ cal BC, but a slightly longer phase for crust and birch bark tar, $3840 \pm 90$ to $3440 \pm$ 105 cal BC. While the southwest Finnish Typical Comb Ware consists of only 10 crust and birch bark tar dates, the values from the whole distribution area are considered as the dating for the whole phase, i.e. 3800-3545 cal BC. However, it is interesting to note that the Southwest Finnish dates in particular raise the possibility for an overlap between Typical Comb Ware and Jäkärlä Ware. Within Typical Comb Ware, 16 charred crust dates were corrected for the reservoir effect.

Late Comb Ware dates are from the coastal area of Finland and six stable carbon isotope values in the crust reflect the marine components in it, and thus a need for the reservoir estimate in the dates. This is shown in the results of the runs, where in the crust and birch bark tar runs the difference between uncorrected and corrected dates is almost 200 years in the start boundary mean values. This emphasizes the importance of marine resources within the Late Comb Ware culture. With reservoir corrected dates, the result of the runs for the whole dataset is $3660 \pm$ 75 to $2940 \pm 125 \mathrm{cal} \mathrm{BC}$ and for crust and birch bark tar dates the values are $3540 \pm 95$ to $3195 \pm 100 \mathrm{cal}$ BC. The dating for Late Comb Ware in Finland and the Karelian Isthmus would be $c$. 3540-3195 cal BC. Taking into account the sensitivity analysis with an alternative $100 \%$ marine limit, the span of Late Comb Ware would be $c$.3635-3165 cal BC.

The results clearly show that the large range especially in charcoal dates distorts the chronological picture, and that the dates from the charred crust or birch bark tar in the surface of the ceramic itself form a much more concise and coherent sequence. The application of the reservoir effect correction changes the date limits to some extent, but rarely more than some tens of years. The greatest difference seems to be for Late Comb Ware, where the beginning of the use of this type of ceramic is almost 200 years younger with the correction applied than it would be without it. The indicated marine orientation in the use of Late Comb Ware pots is an interesting observation and calls for studies into the ecological strategies adopted during this stage.

8 Southwest Finland comprising in this case three counties: Uusimaa, Finland Proper and Satakunta. 


\begin{tabular}{|c|c|c|c|c|c|c|c|}
\hline & $\begin{array}{l}\text { Without } \\
\text { reservoir } \\
\text { correction, } \\
\text { mean value } \\
\text { (calBC) }\end{array}$ & $\begin{array}{l}\text { Without } \\
\text { reservoir } \\
\text { correction, } \\
68 \% \text { HPD } \\
\text { region (calBC) }\end{array}$ & $\begin{array}{l}\text { Without } \\
\text { reservoir } \\
\text { correction, } \\
\text { 95\% HPD } \\
\text { region (calBC) }\end{array}$ & $\begin{array}{l}\text { With } \\
\text { reservoir } \\
\text { correction, } \\
\text { mean value } \\
\text { (calBC) }\end{array}$ & $\begin{array}{l}\text { With } \\
\text { reservoir } \\
\text { correction, } \\
68 \% \text { HPD } \\
\text { region }(\text { calBC) }\end{array}$ & $\begin{array}{c}\text { With } \\
\text { reservoir } \\
\text { correction,95\% } \\
\text { HPD region } \\
\text { (calBC) }\end{array}$ & \\
\hline Jäkärlä class 1 & $4070 \pm 50$ & $4090-4020$ & $4180-3995$ & $4055 \pm 50$ & $4080-4000$ & $4160-3980$ & \\
\hline dates $(n=15)$ & $3550 \pm 60$ & $3620-3525$ & $3635-3425$ & $3550 \pm 65$ & $3620-3525$ & $3635-3420$ & \\
\hline Jäkärlä class 2 & $4700 \pm 105$ & $4780-4575$ & $4910-4500$ & $4700 \pm 110$ & $4780-4575$ & $4915-4505$ & $*$ \\
\hline dates $(n=30)$ & $3355 \pm 105$ & $3475-3285$ & $3550-3135$ & $3350 \pm 110$ & $3475-3280$ & $3550-3120$ & \\
\hline Jäkärlä only crust & $4035 \pm 40$ & $4055-3990$ & $4105-3975$ & $4030 \pm 50$ & $4050-3980$ & $4120-3960$ & $* *$ \\
\hline$(n=9)$ & $3885 \pm 55$ & $3945-3870$ & $3955-3770$ & $3830 \pm 80$ & $3930-3790$ & $3950-3675$ & \\
\hline Sperrings 1 / & $5555 \pm 40$ & $5590-5515$ & $5620-5490$ & $5560 \pm 40$ & $5595-5515$ & $5630-5490$ & \\
\hline Ka $1: 1$ all $(n=82)$ & $4175 \pm 45$ & $4243-4155$ & $4325-4080$ & $4170 \pm 45$ & $4225-4150$ & $4235-4075$ & \\
\hline Sperrings 1 / Ka 1:1 & $5160 \pm 50$ & 5195-5095 & $5260-5070$ & $5155 \pm 50$ & $5190-5095$ & $5250-5070$ & \\
\hline crust and bbt $(n=40)$ & $4340 \pm 50$ & $4425-4295$ & $4435-4255$ & $4335 \pm 50$ & $4405-4285$ & $4435-4255$ & \\
\hline Sperrings 2 / & $4525 \pm 35$ & $4550-4485$ & $4460-4525$ & $4525 \pm 40$ & $4550-4485$ & $4605-4460$ & \\
\hline Ka $1: 2$ all $(n=26)$ & $4075 \pm 110$ & $4215-3915$ & $4225-3865$ & $4050 \pm 110$ & $4205-3900$ & $4220-3855$ & \\
\hline Sperrings 2 / Ka 1:2 & $4510 \pm 35$ & $4540-4475$ & $4556-4420$ & $4510 \pm 40$ & $4540-4475$ & $4600-4415$ & \\
\hline crust and bbt $(n=18)$ & $4240 \pm 40$ & $4290-4210$ & $4353-4101$ & $4225 \pm 50$ & $4290-4200$ & $4310-4125$ & \\
\hline \multirow[t]{2}{*}{ TCW all $(n=188)$} & $3930 \pm 30$ & $3950-3905$ & $3970-3880$ & $3920 \pm 30$ & $3950-3895$ & $3965-x x x x$ & \\
\hline & $3335 \pm 20$ & $3345-3325$ & $3355-3310$ & $3345 \pm 45$ & $3350-3320$ & $3475-3300$ & \\
\hline TCW crust and birch & $3825 \pm 25$ & $3840-3800$ & $3885-3780$ & $3800 \pm 25$ & $3825-3780$ & $3840-x x x x$ & \\
\hline bark tar $(n=72)$ & $3550 \pm 30$ & $3580-3525$ & $3600-3500$ & $3545 \pm 30$ & $3585-3530$ & $x x x x-3495$ & \\
\hline TCW SW Finland all & $3900 \pm 50$ & $3950-3845$ & $3990-3810$ & $3900 \pm 60$ & $3970-3840$ & $4005-3780$ & \\
\hline$(n=34)$ & $3530 \pm 60$ & $3605-3500$ & $3620-3420$ & $3445 \pm 85$ & $3535-3375$ & $3600-3285$ & \\
\hline TCW SW Finland & $3920 \pm 75$ & $3970-3830$ & $4075-3800$ & $3840 \pm 90$ & $3890-3730$ & $4000-x x x x$ & \\
\hline crust and bbt $(n=10)$ & $3560 \pm 65$ & $3635-3530$ & $3655-3420$ & $3440 \pm 105$ & $3565-3365$ & $x x x x-3260$ & \\
\hline \multirow[t]{2}{*}{ Late CW all $(n=23)$} & $3735 \pm 70$ & $3785-3660$ & $3890-3595$ & $3660 \pm 75$ & $3720-3580$ & $3825-x x x x$ & \\
\hline & $2905 \pm 115$ & $3065-2780$ & $3250-2675$ & $2940 \pm 125$ & $3080-2805$ & $3235-2730$ & \\
\hline Late CW crust and & $3710 \pm 85$ & $3795-3640$ & $3875-3540$ & $3540 \pm 95$ & $3630-3395$ & $3715-3380$ & \\
\hline bbt $(n=12)$ & $3140 \pm 100$ & $3275-3060$ & $3325-2950$ & $3195 \pm 100$ & $3325-3140$ & $3340-3000$ & \\
\hline
\end{tabular}

Tab. 2. The resulting table of the analysis. The models used are so-called single-phase models (see Pesonen et al. 2012.Tab. 2). The first and last values in the given cell are the start boundary and the end boundary, respectively, while xxxx denotes that the boundary could not be solved. In the analysis, OxCal 4.2 was used (Bronk Ramsey 2009a), with the calibration curve IntCal 13 (Reimer et al. 2013). Those values marked in bold are used for the further analysis and describing the most probable boundaries for the use-period of given ceramic types. TCW = Typical Comb Ware; $C W=C o m b$ Ware.

In summary, our radiocarbon results provide a significantly more robust chronological framework for the Early and Middle Neolithic ceramic groups in Finland and Eastern Fennoscandia, because of the new charred crust and birch bark tar measurements.

\section{Discussion}

\section{Shoreline dating of Jäkärlä Ware and related ceramics}

The shoreline chronology of the Baltic Sea is based on observations on shore formations and pollen and the diatom stratigraphy of bogs. For the absolute chronology, radiocarbon dates of several lake isolation horizons have been used. For southwest Finland, the basic work was accomplished in 1976 by Gunnar Glückert. New material and dates were presented by Matti Eronen et al. (2001) and Lassi Ha- takka and Gunnart Glückert (2000). The last mentioned study shows the calibrated shore diagrams for five separate areas in southwest Finland. These diagrams have aroused some concern among archaeologists who feel that calibrated shore diagrams give too old dates for the shorebound archaeological sites, especially Stone Age settlement sites (Lehtonen 2005; Asplund 2006; Tiitinen 2011).

Henrik Asplund has illustrated the problem by tentatively re-calibrating the old isolation radiocarbon dates presented by Glückert (1976). This shoreline diagram fits much better with the radiocarbon date from the Turku Jäkärlä site and the Typical Comb Ware (Ka 2) and Earlier Late Comb Ware (Ka 3:1/ Uskela Ware) occupation zone levels at the same site than with the diagram presented by Hatakka and Glückert (2000) (Asplund 2006.5, Fig. 2). 
One problem in testing the shoreline diagrams has been the lack of reliable archaeological radiocarbon dates that could be used to correlate the diagrams (Asplund 2006.4). In the present paper a number of new radiocarbon dates are from the Turku region, the area covered in Asplund's paper, thus giving a possibility to evaluate the shoreline diagrams once more.

The diagram was reproduced from Asplund's paper (2006.5, Fig. 2).9 The radiocarbon dates of Jäkärlä, Typical Comb Ware (Ka 2) and Late Comb Ware (Ka 3 ) were calibrated and their mean value was plotted on the diagram, which shows both the calibrated old curve with error margins (68.2\%) by Glückert (1970) and the new calibrated curve by Hatakka and Glückert (2000). It is obvious that the radiocarbon dates settle better with the old curve than the new curve (Fig. 5). The height difference between the lower limits of the sites and the mean curve of the Glückert (1970) varies between 0 and $5.5 \mathrm{~m}$, while the same variation between the lower limits and the curve by Hatakka and Glückert (2000) is $c$. 1.5$10 \mathrm{~m} .10$ On the basis of the new radiocarbon dates, it seems that the curve presented by Glückert (1976) is a better fit with the archaeological material. New datings from the other sites and the calibration and re-evaluation of the new isolation dates in Eronen $e t$ al. (2001) and Hatakka and Glückert (2000) would probably further improve the shoreline diagrams in Southwestern Finland.

\section{Jäkärlä Ware among the Early and Middle Neolithic ceramic traditions in eastern Fenno- scandia}

The new date ranges give a chance to further discuss the cultural succession between ceramic assemblages, cultures or even populations ( $c f$. Figs. 3-4). According to the new results, the transformation of Sperrings 1 to Sperrings 2 happened between $c$. 4500-4300 cal BC. In the earlier work, by assuming phase independence, the end of Sperrings 1 was dated to $4360 \pm 60 \mathrm{cal} \mathrm{BC}$ and the beginning of Sperrings 2 to $4365 \pm 95 \mathrm{cal} \mathrm{BC}$ (Pesonen et al. 2012), but new dates favour an earlier beginning for Sperrings 2 (especially the Pielavesi Kivimäki site (Nordqvist, Mökkönen 2016)). 11 The Bayesian model takes account of the new dates in a reasonable way. While the new dates push the end of Sperrings 1 to an even younger direction, until $4335 \pm 50 \mathrm{cal} \mathrm{BC}$, and the beginning of Sperrings 2 to $4510 \pm 40 \mathrm{cal} \mathrm{BC}$, a direct succession from Sperrings 1 to Sperrings 2 does not seem probable anymore ( $c f$. Pesonen et al. 2012) as the two ceramic styles clearly overlap chronologically. Still, we would suggest a closer style analysis of these ceramics and see whether all the style determinations are still valid and in line with each

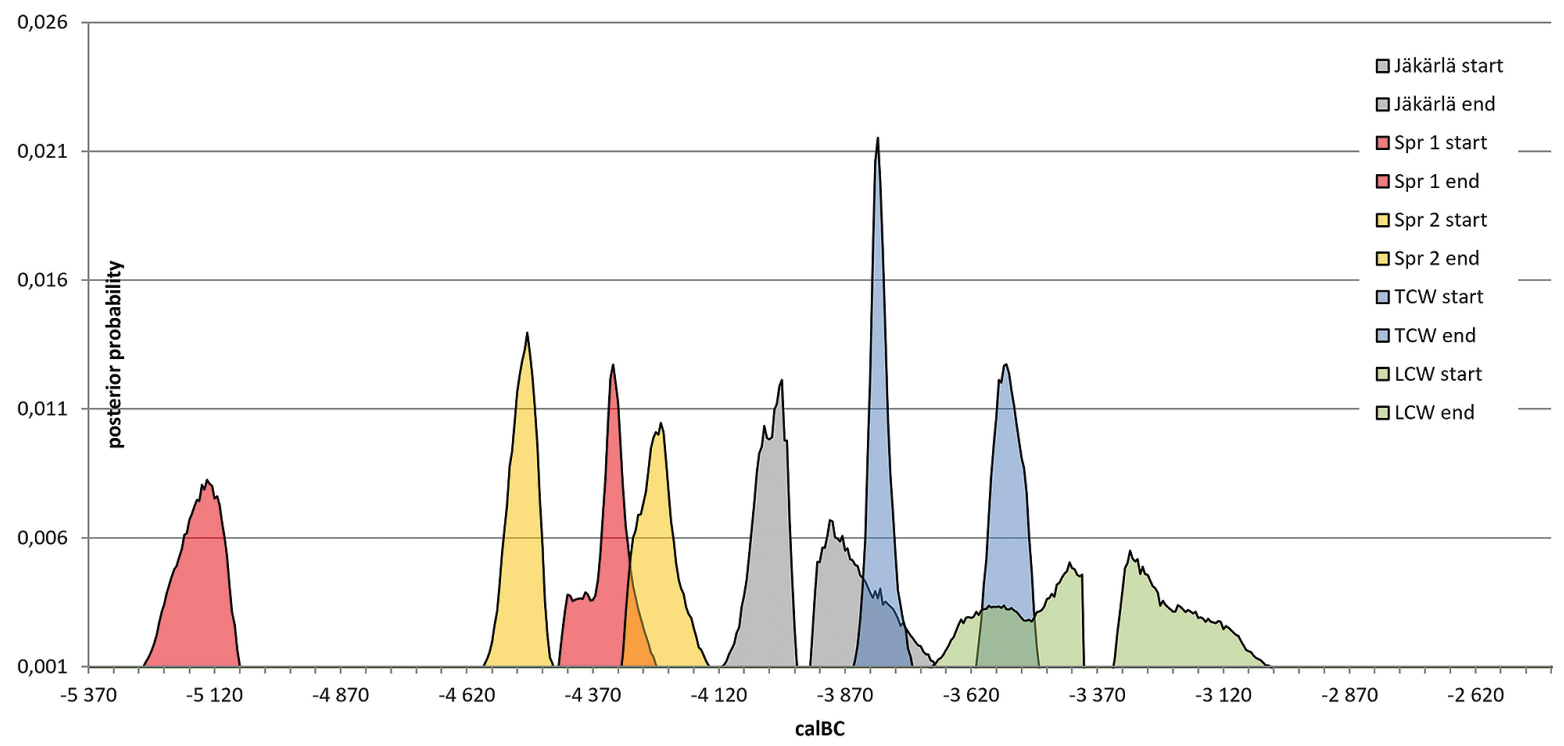

Fig. 3. The posterior probability distributions for the start and end boundaries of each ceramic group. The distributions are from the Bayesian model runs with crust and birch bark tar datings with reservoir correction applied (Tab. 2).

9 The original calibrations were kindly given for the author's use by Henrik Asplund, which is acknowledged.

10 The definition of the lower limit of the site is often based on the very superficial notion in the Register of the Ancient Monuments and in some cases in the literature. The limit cannot thus be taken as an accurate measurement.

11 The model in Pesonen et al. (2012) was created two-ways: as a single-phase model and as a two-phase model. The referred dates are single-phase model (independent) boundaries. 


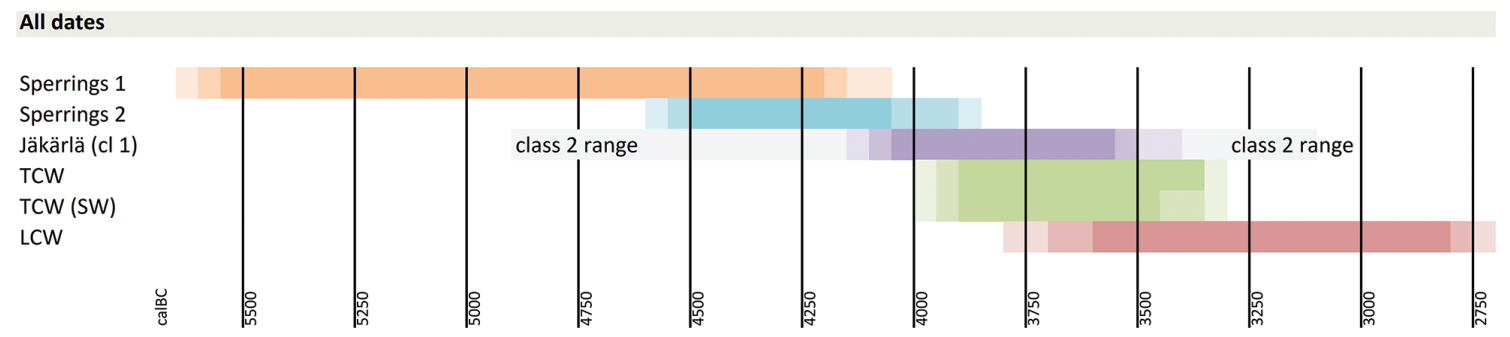

Crust and birch bark tar dates

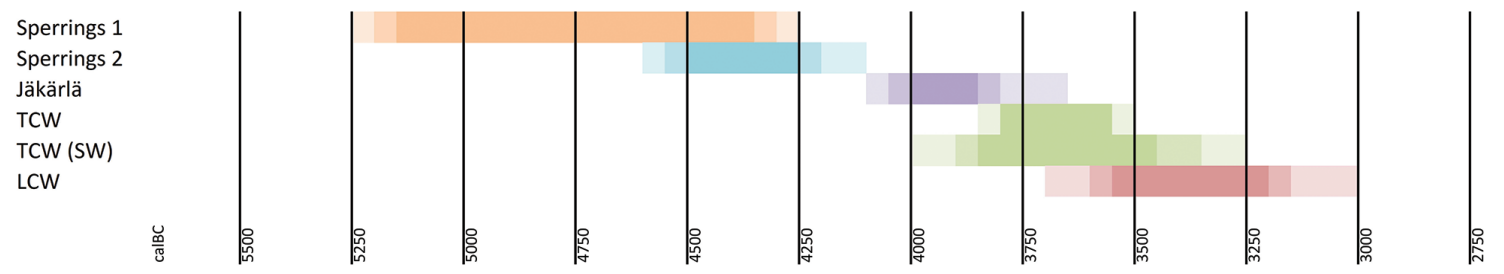

Fig. 4. The date ranges for the studied ceramic types. The shading implies 95\%, 68\% HPD region and mean values for the model runs with reservoir correction applied. TCW= Typical Comb Ware, LCW=Late Comb Ware.

other. Further dates would further illuminate the overlapping period between Sperrings 1 and 2 Wares.

Perhaps the most interesting result is the time-gap between the end of Sperrings 2 Ware and the beginning of Jäkärlä Ware. According to Jäkärlä Ware crust dates (and also class 1 dates), Jäkärlä Ware starts $4030 \pm 50 \mathrm{cal}$ BC while Sperrings 2 Ware ends $4225 \pm 50$ cal BC. This implies that a connection between Sperrings Ware and Jäkärlä Ware is not plausible ( $c f$. Figs. 3-4) undermining the old idea of Jäkärlä Ware being a subgroup of Sperrings 2 Ware. However, a new question arises: where does the Jäkärlä Ware come from?

The end of Jäkärlä Ware is dated according to crust dates to $3830 \pm 80 \mathrm{cal} \mathrm{BC}$, but with the other (class 2) dates counted in, to a much later time, until 3350土 110 cal BC. According to shoreline chronology, the shorter chronology is more suitable for Jäkärlä Ware. Furthermore, there are in practice only the two Eura Kolmhaara dates (Hela-650 and Hela-651) and the set of Kemiönsaari Nöjis dates, which pull the range too young for the end boundary.

Typical Comb Ware has a lot of dates, and correspondingly the Bayesian model gives quite sharp boundaries for this tradition. There is no big difference in the beginning of Typical Comb Ware in any of the model alternatives. The boundaries given by charred crust and birch bark tar dates from the whole country confirm that Typical Comb Ware starts $c .3800 \mathrm{cal} \mathrm{BC}$. It is interesting that the end of Jäkärlä Ware and the beginning of Typical Comb Ware actually overlap, and this indicates their partial contemporaneity. This observation allows for a question as to whether these two ceramic groups are also archaeologically connected in time and space. One key site in this potential connection is Aisti in Mynämäki, which has yielded crust dates for both Jäkärlä Ware and Typical Comb Ware. Jäkärlä sherd was dated 5055 \pm 41 BP (Hela-3076) and Typical Comb Ware sherd 5071 \pm 42 BP (Hela-3077). However, after reservoir correction the latter is slightly younger, $5006 \pm 53 \mathrm{BP}$. As the individual calendaryear probability distributions overlap, ceramics have possibly been used contemporaneously at the same site. Another interesting site is Kukonharju 2 in Nousianen, with two crust dates from Jäkärlä of $5230 \pm$ $41 \mathrm{BP}$ (Hela-2660) and 5177 $\pm 37 \mathrm{BP}$ (Hela-2661), and one crust date from Typical Comb Ware of $4829 \pm 40$ BP (Hela-3178). The Jäkärlä dates are much younger when corrected, $5051 \pm 97 \mathrm{BP}$ and $4953 \pm 116 \mathrm{BP}$, respectively, but the Typical Comb Ware date goes even younger to $4560 \pm 137 \mathrm{BP}$. So, at this site, the pattern seems to be quite clear and no contemporaneity is observed. These are the only two sites where both Jäkärlä Ware and Typical Comb Ware charred crust or birch bark tar dates are available.

The beginning of Late Comb Ware is fairly concise regardless of dating material, though the crust and birch bark tar set gives a $c .100$ years younger start for the style, $c .3540 \mathrm{cal} \mathrm{BC}$. The most interesting thing is that the end of Typical Comb Ware (according to crust and birch bark tar dates) is put at almost exactly the same date. This suggests these two ceramic groups follow each other chronologically. The $\mathrm{RE}$ correction especially affects the Late Comb Ware dates. Without correction, the beginning of Late Comb Ware would be almost 200 years older. The apparent chronological overlap of Typical and Late 


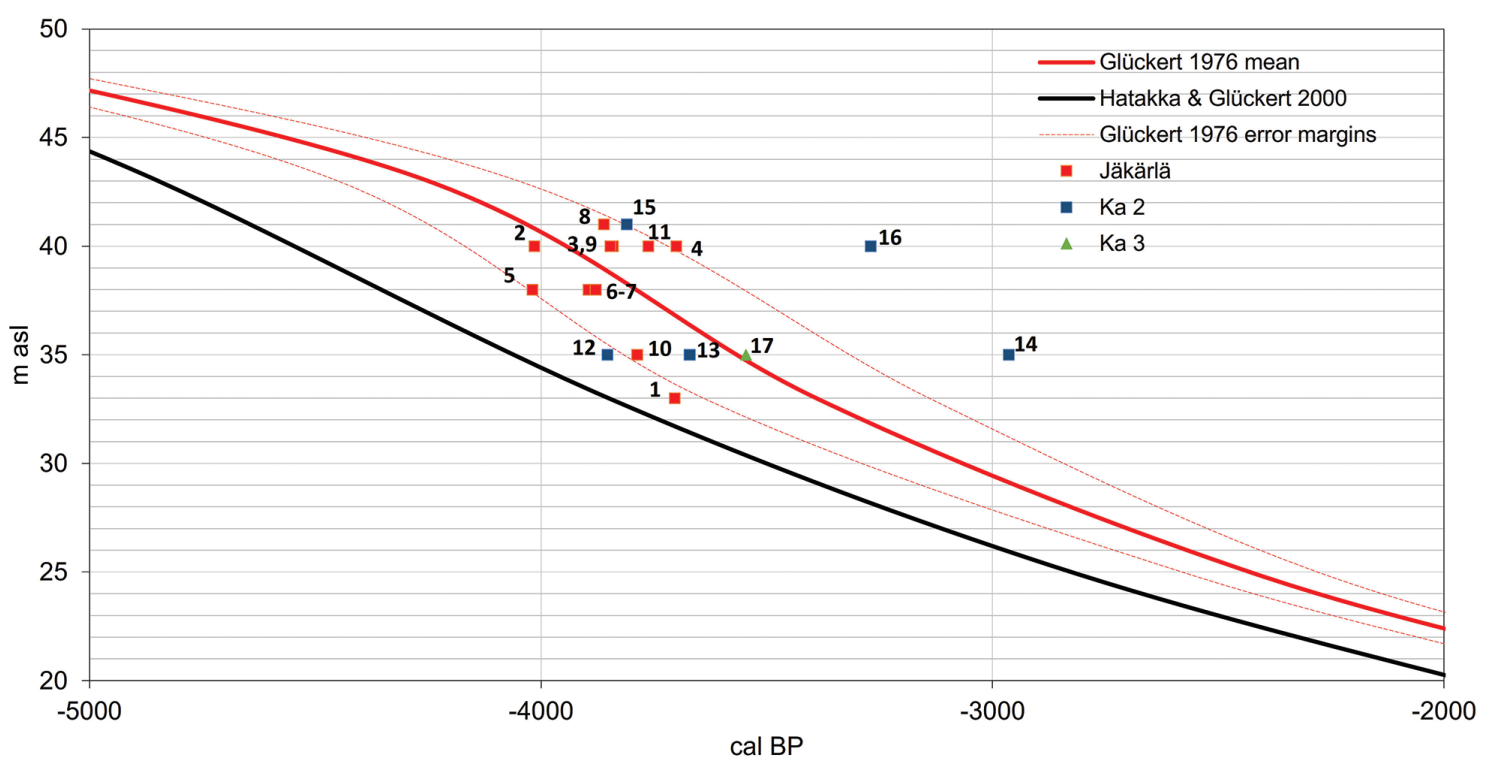

Fig. 5. The shoreline diagrams by Glückert (1976) and Hatakka and Glückert (2000) with radiocarbon dates and elevation of sites in Turku region. The radiocarbon dates with calibrated mean values: Jäkärlä dates - 1 Sauvo Nummenharju, Hela-3165 (4926士35 BP, $3704 \pm 30$ cal BC); 2 Nousiainen Rauanniittu,

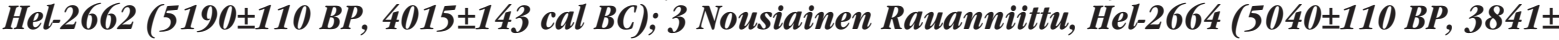

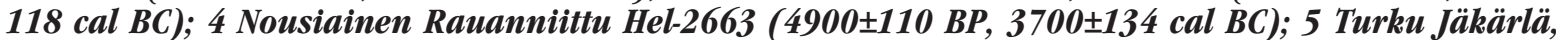

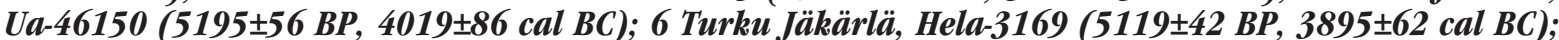

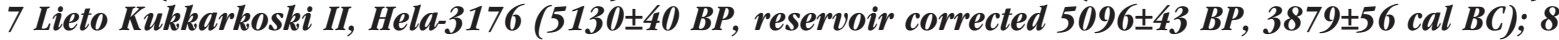

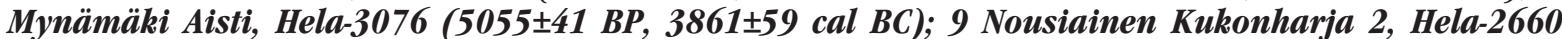
(5230 $\pm 41 \mathrm{BP}$, reservoir corrected 5051 $\pm 97 \mathrm{BP}, 3847 \pm 105$ cal BC); 10 Lieto Merola, Hela-3172 (5002 $\pm 40 \mathrm{BP}$,

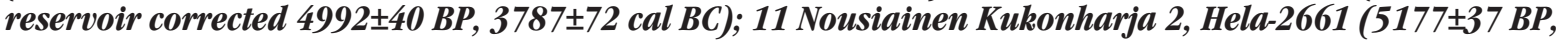
reservoir corrected $4953 \pm 116$ BP, $3762 \pm 110$ cal BC); Typical Comb Ware dates - 12 Lieto Kukkarkoski I, Hela-118 (5060 \pm 65 BP, $3853 \pm 75$ cal BC); 13 Lieto Kukkarkoski I, Hel-832 (4880 \pm 150 BP, $3671 \pm 180$ cal BC);

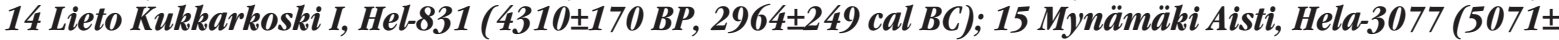

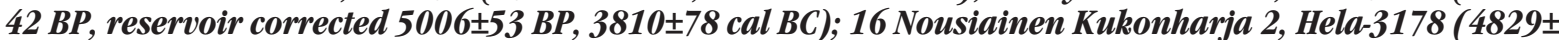
$40 \mathrm{BP}$, reservoir corrected $4560 \pm 137 \mathrm{BP}, 3270 \pm 189$ cal BC); and Late Comb Ware date - 17 Nousiainen Kuuvanvuori, Hela-979 (4775 \pm 55 BP, $3546 \pm 76$ cal BC).

Comb Ware is a problem recognized in earlier publications (e.g., Leskinen 2003; Leskinen, Pesonen 2008; Räihälä 1996) but understandable in the light of reservoir effect, which particularly affects the oldest Late Comb Ware dates from the sites Maarinkunnas in Vantaa and Kuuvanvuori in Nousiainen. This corresponds well with the lipid and isotope studies performed for Typical and Late Comb Ware pots showing substantial use of marine food (Leskinen 2003; Pesonen, Leskinen 2009; Cramp et al. 2014) which agrees with the high $\delta^{13} \mathrm{C}$ - values in the food crusts of these items.

\section{Conclusions}

Our new dates and their modelling inside a Bayesian framework give a clear and concise picture of the chronological position of southwestern Finnish Jäkärlä Ware. The use period of this ceramic type is dated to $c$. 4030-3830 cal $\mathrm{BC}$, which is a considerably shorter period than previous radiocarbon dates have lead us to think. According to this study the model dating of Sperrings 1 Ware is $c .5155-4335$ cal BC and Sperrings 2 Ware $4510-4225$ cal BC. These figures are fairly consistent with earlier studies (Pesonen et al. 2012; Nordqvist, Mökkönen 2017), and would imply an overlap period between Sperrings 1 and 2 ceramics. However, there is no overlap whatsoever between the periods of Sperrings 2 and Jäkärlä Wares. The dating of Typical Comb Ware was already fixed in earlier studies (Pesonen 1999; 2004; Oinonen et al. 2014), and now the borders are only closing in so that the Typical Comb Ware begins $c$. $3800 \mathrm{cal} \mathrm{BC}$ and ends soon after, c. $3545 \mathrm{cal} \mathrm{BC}$. According to the data in this study, the production of Late Comb Ware begins right after Typical Comb Ware and lasts until c. $3195 \mathrm{cal} \mathrm{BC}$.

Several consequences on the chronological succession of ceramic types follow from the results. First, Jäkärlä pottery is chronologically (and spatially) a limited phenomenon, which does not seem to have roots in Sperrings (Ka 1:1 or Ka 1:2) pottery, which must be sought elsewhere. So far, there are no para- 
gons for Jäkärlä Ware. Secondly, Jäkärlä pottery may have existed contemporaneously with Typical Comb Ware, but the scenario is still not clear with regard to these two styles. Most likely Jäkärlä pottery and its users were there sometime together with Typical Comb Ware, before the Jäkärlä tradition finally ceased. The situation may have been somewhat similar to the circumstances in eastern Finland and between Early Asbestos Ware and Typical Comb Ware (cf. Oinonen et al. 2014). Thirdly, we find it very unlikely that Jäkärlä pottery and Late Comb Ware (or any other Middle or Late Neolithic pottery type) would have any chronological contacts with each other. The few dates pointing to the late existence of Jäkärlä pottery are from Nöjis and Kolmhaara sites, but they are both controversial and unfit for the shoreline chronology as well.

The new chronology for the Jäkärlä Ware also implies that the sometimes postulated (e.g., Pesonen 1996; 2001) connection between eastern Finnish Early Asbestos Ware and Jäkärlä Ware is difficult to understand. Early Asbestos Ware was produced between $c$. 4670-3845 cal BC (Oinonen et al. 2014), i.e. starting long before Jäkärlä Ware and coming to end along with the appearance of Typical Comb Ware. According to the new interpretation the term
'Early Asbestos Ware' should be rejected, and the terms 'asbestos-tempered Sperrings 2 Ware' and 'Kaunissaari Ware' should probably be used instead (Nordqvist 2018). This division carries chronological significance. Although not yet studied, it is possible that Kaunissaari-type Early Asbestos Ware is younger than asbestos-tempered Sperrings 2 Ware, and indeed may overlap chronologically with Jäkärlä Ware. A geographical gap still separates two ceramic traditions, but the possible connection is worthy of further investigation, and may reveal a hitherto unknown typo-chronological period that exists between Sperrings 1-2 Wares and Typical Comb Ware.

The Appendices 1-4 are available at http://dx.doi.org/10.4312/dp.46.15

The authors wishes to thank Päivi Kankkunen and Simo Vanhatalo, of the Finnish Heritage Agency, for letting us use their unpublished radiocarbon dates in this study and Henrik Asplund, University of Turku, for help with the manuscript. Miikka Tallavaara is thanked for the help in the mathematics. The study has partly been financed by the Emil Aaltonen Foundation.

\section{$\therefore$}

\section{References}

Aalto M., Taavitsainen J.-P., and Vuorela I. 1981. Palaeobotanical investigations at the site of a sledge runner find, dated to about 4900 BP, in Noormarkku, SW Finland. Suomen Museo 1980: 41-65.

Ahokas H. 2012. Crop evolution under fire: The past cultivation with sequential kytö burning selected against the shattering weedy forms and comparison between Finnish kytö and Ethiopian guie. Interdisciplinary Biology, Agriculture, Linguistics and Antiquities 5. Kave. Helsinki.

Asplund H. 1990. Nöjis - en exkurs I kulturbegrepp och dateringsproblematik. In H. Myhrman (ed.), Från säljägare till rösbyggare. Stenåldern I Dragsfjärd ur en amatörarkeologs synvinkel. Åbo Akademi. Åbo: 20-28.

1995. Radiocarbon dating of Jäkärlä ceramics - a comment on Comb Ceramic chronology and typology. Karhunhammas 16: 69-75.

1997. Kemiön suurpitäjän esihistoria. Kemiön suurpitäjän historia I. Sagalundin museon kuntayhtymä. Tammisaari: 213-286.
1998. Cultural groups and ethnicity. A Comb Ceramic case. Etnicitet eller kultur. Mitthögskolan. Östersund: 79-99.

2006. Muinaisranta etääntyy Lounais-Suomessa - Geologian vai arkeologian ongelma? Muinaistutkija 4: 2-10.

2008. Kymittae. Sites, centrality and long-term change in the Kemiönsaari region in SW Finland. Turun yliopiston julkaisuja. Sarja B (312), Humaniora. Turku.

Bayliss A. 2009. Rolling out Revolution: Using Radiocarbon Dating in Archaeology. Radiocarbon 51: 123-147. https://doi.org/10.1017/S0033822200033750

2015. Quality in Bayesian chronological models in archaeology. World Archaeology 47(4): 677-700. https://doi.org/10.1080/00438243.2015.1067640

Bronk Ramsey C. 2009a. Bayesian analysis of radiocarbon dates. Radiocarbon 51: 337-360.

2009b. Dealing with Outliers and Offsets in Radiocarbon Dating. Radiocarbon 51: 1023-1045. https://doi.org/10.1017/S0033822200034093 
Buck C., Kenworthy J., Litton C., and Smith A. 1991. Combining archaeological and radiocarbon information: a Bayesian approach to calibration. Antiquity 65(249): 808821.

Carpelan C. 1979. Om asbestkeramikens historia i Fennoskandien. Finskt Museum 1978: 5-25.

1999. Käännekohtia Suomen esihistoriassa aikavälullä 5100-1000 eKr. In P. Fogelberg (ed.), Pohjan poluilla. Suomalaisten juuret nykytutkimuksen mukaan. Bidrag till kännedom av Finlands natur och folk, 153. The Finnish Society of Sciences and Letters. Helsinki: 249280.

Carpelan C., Uino P., and Gerasimov D. V. 2008. Archaeology in the former Municipality of Johannes. In M. Lavento, K. Nordqvist (eds.), Karelian Isthmus. Stone Age Studies 1998-2003. Iskos 16: 185-214.

CHRONO Marine database, http://calib.org/marine/

Cramp L. J. E., Evershed R. P., Lavento M., Halinen P., Mannermaa K., Oinonen M., Kettunen J., Perola M., Onkamo P., and Heyd V. 2014. Neolithic dairy farming at the extreme of agriculture in northern Europe. Proceedings of the Royal Society B 281: 20140819.

http://dx.doi.org/10.1098/rspb.2014.0819

Costopoulos A., Vaneeckhout S., Okkonen J., Hulse E., Paberzyte I., and Wren C. D. 2012. Social complexity in the Mid-Holocene Northeastern Bothnian Gulf. European Journal of Archaeology 15(1): 41-60.

https://doi.org/10.1179/1461957112Y.0000000005

Edinborough K. 2009. Population history and the evolution of Mesolithic arrowhead technology in Scandinavia. In S. Shennan (ed.), Pattern and Process in Cultural Evolution. University of California Press. Berkley CA: 191-202.

Edinborough K., Martindale A., Cook G. T., Supernant K., and Ames K. M., 2016. A marine reservoir effect $\Delta \mathrm{R}$ value for kitandach, in Prince Rupert Harbour, British Columbia, Canada. Radiocarbon 58(4): 885-891.

https://doi.org/10.1017/RDC.2016.46

Edinborough K., Shennan S.J., Crema E. R., and Kerig T. 2015. An ABC of lithic arrowheads: a case study from south-eastern France. In K. Brink, S. Hydén, K. Jennbert, L. Larsson, and D. Olausson (eds.), Neolithic Diversities. Acta Archaeologica Lundensia, Series 80, vol. 65. Department of Archaeology and Ancient History. Lund University. Lund: 213-223.

Edgren T. 1966. Jäkärlä-gruppen. En västfinsk kulturgrupp under yngre stenålder. Suomen Muinaismuistoyhdistyksen Aikakauskirja 64. Finska fornminnesföreningen. Helsinki.
1983. Formgivning och funktion. En kamkeramisk studie. Iskos 3. Suomen muinaismuistoyhdistys. Helsinki.

1999. Alkavan rautakauden kulttuurikuva Länsi-Suomessa. In P. Fogelberg (ed.), Pohjan poluilla. Suomalaisten juuret nykytutkimuksen mukaan. Bidrag till kännedom av Finlands natur och folk, 153. The Finnish Society of Sciences and Letters. Helsinki: 311-333.

Eronen M., Glückert G., Hatakka L., van der Plassche 0., van der Plicht J., and Rantala P. 2001. Rates of Holocene isostatic uplift and relative sea-level lowering of the Baltic in SW Finland based on studies of isolation contacts. Boreas 30: 17-30.

Etu-Sihvola H., Bocherens H., Drucker D., Junno A., Mannermaa K., Oinonen M., Uusitalo J., and Arppe L. 2019. The dIANA database - Resource for isotopic paleodietary research in the Baltic Sea area. Journal of Archaeological Science: Reports 24: 1003-1013.

www.oasisnorth.org/dIANA

Europaeus A. 1916. Förvärv till Statens Historiska Museum år 1914, Stenåldern. Finskt Museum 1916: 36-53.

1917. Förvärv till Statens Historiska Museum år 1915. Stenåldern. Finskt Museum 1917: 39-58.

1922. Fornfynd från Kyrkslätt och Esbo socknar. Suomen Muinaismuistoyhdistyksen Aikakauskirja XXXII. Puromie. Helsinki.

1925. Kansallismuseon kivikauden kokoelmain kasvu vuosina 1920-1923. Suomen Museo 1925: 12-54.

1926. Stenålderskeramik från kustboplatser i Finland. Suomen Muinaismuistoyhdistyksen Aikakauskirja XXXVI:1: 45-77.

Europaeus-Äyräpää A. 1930. Die relative Chronologie der steinzeitlichen Keramik in Finnland I-II. Acta Archaeologica I. Fasc. 2 \& 3: 165-190, 205-220.

Fernandes R. 2016. A Simple(R) Model to Predict the Source of Dietary Carbon in Individual Consumers. Archaeometry 58(3): 500-512.

https://doi.org/10.1111/arcm.12193

Fischer A., Heinemeier J. 2003. Freshwater reservoir effect in ${ }^{14} \mathrm{C}$ dates of food residue on pottery. Radiocarbon 45 (3): 449-486.

German K. 2009. Early hunter-gatherer ceramics in Karelia. In P. Jordan, M. Zvelebil (eds.), Ceramics before farming: the dispersal of pottery among prehistoric Eurasian hunter-gatherers. Left Coast Press. Walnut Creek: 255-280. 
Glückert G. 1976. Post-Glacial Shore Level Displacement of the Baltic in SW Finland. Annales Academiae Scientiarum Fennicae. Series A III Suomalainen Tiedeakatemia. Helsinki: 118: 1-92.

Hatakka L., Glückert G. 2000. Calibration curves representing shore displacement of the Baltic based on radiocarbon ages in the Karjaa, Perniö, Turku, Mynämäki, and Laitila areas, SW Finland. In A. Nissinaho (ed.), Sites and settlement. Publications of the project Changing Environment - Changing Society. University of Turku, Åbo Akademi University. Turku: 3-14.

Halinen P. 1997. Ajoitustuloksia. Muinaistutkija 3: 53.

Halinen P., Katiskoski K., and Sarkkinen M. 1998. Yli-Iin Kuuselankankaan asuinpaikan tutkimukset 1994-1996. In H. Ranta (ed.), Kentältä poimittua 4. Museoviraston arkeologian osaston julkaisuja 7. Helsinki: 24-40.

Halinen P., Mökkönen T. 2009. Between lake and sea: Stone Age settlement by Ancient Lake Ladoga on the Karelian Isthmus. Fennoscandia Archaeologica XXVI: 107132.

Hallgren F. 2004. Identitet i praktik. Lokala, regionala och överregionala sociala sammanhang inom nordlig trattbägarkultur. Coast to coast book 17. Uppsala University. Stockholm.

Hertell E., Manninen M. A. 2006. House-pit formation processes - a preliminary assessment of pit 4 at Rävåsen, southern Ostrobothnia, Finland. In V.-P. Herva (ed.), People, Material Culture and Environment in the North. Proceedings of the 22nd Nordic Archaeological Conference, University of Oulu, 18-23 August 2004. Studia humaniora ouluensia 1. University of Oulu. Oulu: 183-197.

Huurre M. 1991. Satakunnan kivikausi. In Satakunnan historia I, 1. Rauma: Satakunnan Maakuntaliitto ry. ja Satakuntalitto: 87-323.

Hüls C.M., Nadeau M. J., Grootes P. M., Erlenkeuser H., and Andersen N. 2010. Experimental study on the origin of cremated bone apatite carbon. Radiocarbon 52: 587599. https://doi.org/10.1017/S0033822200045628

Junno A., Uusitalo J., and Oinonen M. 2015. Radiocarbon dates of Helsinki University. www.oasisnorth.org/carhu. Article in preparation.

Kankkunen P. 2005. Eura Kolmhaara Munasaari, kivikautisen asuinpaikan kaivaus 2002-2004 (Excavation of a Stone Age settlement site). Unpublished excavation report. Archives of the Finnish Heritage Agency, Helsinki, Finland. https://www.kyppi.fi/palveluikkuna/raportti/read/ asp/hae_liite.aspx?id=101950\&ttyyppi=pdf\&kansio_id=50
Karjalainen T. 2002. Comparisons between the artefact assemblages of six Neolithic houses. In H. Ranta (ed.), Huts and houses. Stone Age and Early Metal Age buildings in Finland. National Board of Antiquities. Helsinki: 42-52.

Karmanov V. N., Zaretskaya N. E., and Volokitin A. V. 2014. Another way of pottery distribution in eastern Europe? Case study of the Pezmog 4 site, European Far Northeast. Radiocarbon 56: 733-741.

https://doi.org/10.2458/56.16952

Katiskoski K. 1996. Lisiä Pielisen alueen esihistoriaan: kaivaustutkimuksia Lieksassa 1991-1993. In H. Ranta (ed.), Kentältä poimittua 3. Kirjoitelmia arkeologian alalta. Museoviraston arkeologian osaston julkaisuja 6 . The National Board of Antiquities. Helsinki: 23-36.

Katiskoski K. 2004. Cemetery and the dwelling site Vaateranta in Taipalsaari, southeastern Finland. Suomen Museo 110(2003): 81-125.

Kholkina M. 2018. A group of Late Comb Ware from the Karelian Isthmus. Estonian Journal of Archaeology 22 (2): $96-118$.

Kosinskaya L. L. 2014. Rannyaya grebenchataya keramika v neolite Zauralya. Uralskiy Istoricheskiy Vestnik 43: $30-40$.

Kuokkanen T. 2000. Stone age Sledges of central-grooved type: Finnish reconstructions. Fennoscandia Archaeologica XVII: 37-56.

Lanting J. N., Aerts-Bijma A. T., and van der Plicht J. 2001. Dating of cremated bones. Radiocarbon 43: 249-254. https://doi.org/10.1017/S0033822200038078

Lehtonen K. 2005. Eurajoen Etukämppä - hylkeenpyytäjien ja kalastajien tukikohta muinaisen Panelianlahden rannalla. In H. Ranta (ed.), Kentältä poimittua 6. Kirjoitelmia arkeologian alalta. Museoviraston arkeologian osaston julkaisuja 11. National Board of Antiquities. Helsinki: 5-18.

Lesell K. 2005. Keramiikan karsta-ajoituksia. In H. Ranta (ed.), Kentältä poimittua 6. Kirjoitelmia arkeologian alalta. Museoviraston arkeologian osaston julkaisuja 11. National Board of Antiquities. Helsinki: 103-105.

Leskinen S. 2002. Late Neolithic House at Rusavierto. In H. Ranta (ed.), Huts and houses. Stone Age and Early Metal Age buildings in Finland. National Board of Antiquities. Helsinki: 147-169.

2003. On the dating and function of the Comb Ceramics from Maarinkunnas. Finskt Museum 1995: 5-43. 
Leskinen S., Pesonen P. 2008. Vantaan esihistoria. Vantaan kaupunki. Vantaa.

Lougheed B. C., Filipsson H. L., and Snowball I. 2013. Large spatial variations in coastal ${ }^{14} \mathrm{C}$ reservoir age - a case study from the Baltic Sea. Climate of the Past 9: 10151028 .

Luho V. 1948. Suomen kivikauden pääpiirteet. Otavan kulttuurisarja. Otava. Helsinki.

1952. Den kamkeramiska kulturen. In C. F. Meinander (ed.), Forntid och fornfynd. En översikt av Finlands förhistoria $i$ den moderna arkeologins belysning. Holger Schildts Förlag. Helsingfors: 12-18.

Luoto J., Terho A. 1988. Kuoppakeraaminen astia Nousiaisten Kirjunpajusta. Faravid 12: 7-28.

Matiskainen H. 1979. Päijänteen arkeologinen rannansiirtymiskronologia. Tutkimuksia. Lahden museo - ja taidelautakunta. Suomi.

Matiskainen H., Jussila T. 1984. Naarajärven kampakeraaminen asumus. Suomen Museo 1984: 17-52.

Meinander C. F. 1965. Skifferknivar med djurhuvudskaft. Finskt Museum 1964: 5-33.

1971. Radiokarbondateringar till Finland stenålder. Societas Scientiarum Fennica Årsok - Vuosikirja XLVIII B No. 5: 3-14.

1984. Kivikautemme väestöhistoria. Suomen väestön esihistorialliset juuret. Bidrag till kännedom av Finlands natur och folk, H. 131. The Finnish Society of Sciences and Letters. Helsinki: 21-48.

Miettinen M. 2002. Investigations at the Madeneva Stone Age site in Pihtipudas. In H. Ranta (ed.), Huts and houses. Stone Age and Early Metal Age buildings in Finland. National Board of Antiquities. Helsinki: 137-146.

2005. Sammanfattning. In H. Edgren (ed.), Rävåsen. Finskt Museum 2002: 104-112.

Moisanen J. 1991. Tutkimuksia Kerimäen kivikautisilla asuinpaikoilla. Sihti 1: 25-32.

Mäkivuoti M. 1991. Ylikiimigin Latokankaan kivikautinen asuinpaikkatutkimus. Faravid 15/1991: 119-136.

Mökkönen T. 2008. A review of neolithic multi-room housepits as seen from the Meskäärtty site in virolahti parish, extreme south-eastern Finland. Estonian Journal of Archaeology 12(2): 114-151. http://www.kirj.ee-public/Archa eology/2008/issue_2-arch-2008-2-114-151.pdf
Mökkönen T., Nordqvist K. 2016. Quantifying Mineral Raw Materials in Neolithic Knapped Tool Production in the Lake Saimaa Area, Finnish Inland. In P. Uino, K. Nordqvist (eds.), New Sites, New Methods. Proceedings of the Finnish-Russian Archaeological Symposium, Helsinki, 1921 November, 2014. Iskos 21. Vaasa: The Finnish Antiquarian Society: 4-58.

2018. Kierikki Ware and the contemporary Neolithic asbestos- and organic-tempered potteries in North-East Europe. Fennoscandia archaeologica XXXIV (2017): 83-116.

Nieminen E.-L., Ruonavaara L. 1984. Stilisierte Vogeldarstellungen auf gefässcherben aus Kiikarusniemi, Gemeinde Sotkamo und Böle, Gemeinde Porvoo. Fennoscandia archaeologica I: 7-11.

Nordqvist K., Mökkönen T. 2015. Äyräpää's Typical Comb Ware: An umbrella term for the Early $4^{\text {th }}$ millennium BC pottery in northeastern Europe? Fennoscandia archaeologica XXXII: 151-158.

2016. New radiocarbon dates for early pottery in northeastern Europe. In 0. V. Lozovsky, A. N. Mazurkevich, and E. V. Dolbonova (eds.). Traditions and Innovations in the Study of Earliest Pottery. Materials of the International Conference, May, 24-27, 2016, St. Petersburg, Russia. St. Petersburg: 204-214.

2017. Periodisation of the Neolithic and radiocarbon chronology of the Early Neolithic and the beginning of the Middle Neolithic in Finland. Documenta Praehistorica 44: 78-86. https://doi.org/10.4312/dp.44.5

Nordqvist K. 2018. The Stone Age of north-eastern Europe 5500-1800 calBC: bridging the gap between the East and the West. Acta Universitatis Ouluensis, B Humaniora 160 . University of Oulu. Oulu.

Nuñez M. 1990. On Subneolithic pottery and its adoption in Late Mesolithic Finland. Fennoscandia Archaeologica VII: 27-52.

Oinonen M., Vasks A., Zarina G., and Lavento M. 2013a. Stones, Bones and Hillfort - Radiocarbon Dating of Kivutkalns Bronze-Working Centre. Radiocarbon 55: 12521264. https://doi.org/10.1017/S0033822200048165

Oinonen M., Hilasvuori E., Mehtonen H., Uotila K., and Zetterberg P. 2013b. On the eve of urbanization: Bayesian model dating for medieval Turku. Radiocarbon 55(2-3): 1265-1277. https://doi.org/10.1017/S0033822200048177

Oinonen M., Pesonen P., Alenius T., Heyd V., HolmqvistSaukkonen E., Kivimäki S., Nygrén T., Sundell T., and Onkamo P. 2014. Event reconstruction through Bayesian 
chronology: massive mid-Holocene lakeburst triggered large-scale ecological and cultural change. The Holocene 24(11): 1419-1427.

https://doi.org/10.1177/0959683614544049

Olsen J., Heinemeier J., Horsnstrup K. M., Bennike P., and Thrane H. 2012. 'Old Wood' effect in radiocarbon dating of prehistoric cremated bones? Journal of Archaeological Science 40: 30-34.

https://doi.org/10.1016/j.jas.2012.05.034

Olsson I. U. 1980. Content of ${ }^{14} \mathrm{C}$ in marine mammals from northern Europe. Radiocarbon 22: 662-675.

Papakosta V., Pesonen P. 2019. Lipid residues in early hunter-gatherer ceramics from Finland. In K. Mannermaa, M. A. Manninen, P. Pesonen, and L. Seppänen (eds.), Helsinki Harvest. Proceedings of the $11^{\text {th }}$ Nordic Conference on the Application of Scientific Methods in Archaeology. Monographs of the Archaeological Society of Finland 7. The Archaeological Society of Finland. Helsinki: 32-47.

Pesonen P. 1996. Early Asbestos Ware. In T. Kirkinen (ed.), Pithouses and Potmakers in Eastern Finland. Reports of the Ancient Lake Saimaa Project. Helsinki Papers in Archaeology, no. 9. Helsinki: Department of Archaeology. University of Helsinki. Helsinki: 9-39.

1999. Radiocarbon dating of birch bark pitches in Typical Comb Ware in Finland. In M. Huurre (ed.), Dig it all. Papers dedicated to Ari Siiriäinen. The Archaeological Society of Finland. The Finnish Antiquarian Society. Helsinki: 191-200.

2002. Semisubterranean houses in Finland: a Review. In H. Ranta (ed.), Huts and Houses: Stone Age and Early Metal Age Buildings in Finland. National Board of Antiquities. Helsinki: 9-41.

2004. Neolithic pots and ceramics chronology - AMSdatings of Middle and Late Neolithic ceramics in Finland. In P. Uino (ed.), Fenno-Ugri et Slavi 2002, Dating and Chronology. Museoviraston arkeologian osaston julkaisuja no. 10. National Board of Antiquities. Helsinki: 87-97.

2013. Stratigraphy and chronology of a Stone Age pithouse in Raahe, northern Ostrobothnia. In K. Johanson, M. Tõrv (eds.), Man, his time, artefacts, and places. Muinasaja Teadus 19. University of Tartu, Institute of History and Archaeology. Tartu: 517-545.

Pesonen P., Leskinen S. 2009. Pottery of the Stone Age Hunter-Gatherers in Finland. In P. Jordan, M. Zvelebil (eds.), Ceramics Before Farming. The Dispersal of Pottery Among Prehistoric Eurasian Hunter-Gatherers. Left Coast Press. Walnut Creek: 299-318.
Pesonen P., Oinonen M., Carpelan C., and Onkamo P. 2012. Early Subneolithic ceramic sequences in Eastern Fennoscandia - a Bayesian approach. Radiocarbon 54(34): 661-676. https://doi.org/10.1017/S0033822200047330

Pesonen P., Sundell T. 2011. Argeopop-projektin arkeologiset tietokannat. Muinaistutkija 4: 11-18.

Pesonen P., Viljanmaa S., and Oinonen M. 2013. An evidence of Neolithic beeswax in North Ostrobothnia, Finland, on $65^{\circ}$ latitude. $7^{\text {th }}$ International Symposium: ${ }^{14} \mathrm{C}$ and Archaeology: Book of Abstracts. Universiteit Gent. Gent: 139-410.

Piezonka H. 2008. Neue AMS-Daten zur Frühneolithischen Keramikentwicklung in der Nordosteuropäischen Waldzone. Estonian Journal of Archaeology 12(2): 67-113. https://doi.org/10.3176/arch.2008.2.01

2015. Jäger, Fischer, Töpfer: Wildbeutergruppen mit früher Keramik in Nordosteuropa im 6. und 5. Jahrtausend v. Chr. Archäeologie in Eurasien 30. Habelt. Bonn.

Possnert G. 1984. AMS with the Uppsala EN tandem accelerator. Nuclear Instruments and Methods in Physics Research Section B: Beam Interactions with Materials and Atoms 5(2): 159-161.

Pääkkönen M., Bläuer A., Evershed R. P., and Asplund H. 2016. Reconstructing Food Procurement and Processing in Early Comb Ware Period Through Organic Residues in Early Comb and Jäkärlä Ware Pottery. Fennoscandia Archaeologica XXXIII: 57-76.

Rankama T. 1982. Tyylivaihe I:2 Kymenlaaksossa. In H. Edgren, P. Uino (eds.), Studia Minora. The University of Helsinki, Department of Archaeology. Stencil 29: 13-24.

Reimer P. J., and 29 co-authors. 2013. IntCal13 and Marine13 radiocarbon age calibration curves $0-50,000$ years cal BP. Radiocarbon 55(4): 1869-1887.

http://doi.org/10.2458/azu_js_rc.55.16947

Riska T. 1945. Stenåldersfynden från Parkkila i Kjulo. Finskt Museum 1945: 15-29.

Räihälä 0. 1996. A Comb Ware house in Outokumpu Sätös - some remarks on the application of ceramic typologies. In T. Kirkinen (ed.), Pithouses and Potmakers in Eastern Finland. Reports of the Ancient Lake Saimaa Project. Helsinki Papers in Archaeology, no. 9. Department of Archaeology, University of Helsinki. Helsinki: 89-117.

Räty J. 1995. The red-ochre graves of Vaateranta in Taipalsaari. Fennoscandia Archaeologica XII: 161-172.

Salo U., Laukkanen E. 1986. Turku (Entistä Maariaa) Jäkärlä, kivikautisen asuinpaikan kaivaus 6.-17.9.1985. 
(Excavation of a Stone Age settlement site). Unpublished excavation report. Archives of the Finnish Heritage Agency, Helsinki, Finland. https://www.kyppi.fi/palveluikkuna/ra portti/read/asp/hae_liite.aspx?id=104359\&ttyyppi=pdf \&kansio_id=853

Schulz E.-L. 2004. Ankkapurhan arkeologisen aineiston radiohiiliajoitukset. In P. Uino (ed.), Ammoin Ankkapurhassa. Kymenlaaksossa kivikaudella. Museovirasto, Stora Enso, Anjalankosken tehtaat. Jyväskylä: 46.

2006. Joroisten Kanavan radiohiiliajoitukset. In P. Pesonen, T. Mökkönen (eds.), Arkeologipäivät 2005. Arkeologia ja kulttuuri; Uutta kivikauden tutkimuksessa. The Archaeological Society of Finland. Hamina: 132137.

Seitsonen 0., Nordqvist K., and Gerasimov D. 2009. Recent archaeological research in the Lake Pyhäjärvi microregion, Karelian Isthmus, Russia: The multi-period site of Pyhäjärvi Kunnianniemi and some Early Combware period finds. Fennoscandia Archaeologica XXVI: 95-103.

Siiriäinen A. 1969. Über die Chronologie der steinzeitlichen Küstenwohnplätze Finnland im Lichte der Uferverschiebung. Suomen Museo 1969: 40-73.

1973. Studies Relating to Shore Displacement and Stone Age Chronology in Finland. Finskt Museum 1973: 522 .

Slota P. J., Jull A. J. T., Linick T. W., and Toolin L. J. 1986. Preparation of small samples for ${ }^{14} \mathrm{C}$ accelerator targets by catalytic reduction of CO. Radiocarbon 29(2): 303-306.

Stenbäck N. 2003. Människorna vid havet. Platser och keramik på Ålandsöarna perioden 3500-2000 f.Kr. Stockholm Studies in Archaeology 28. Institutionen för arkeologi. Stockholm universitet. Stockholm.

van Strydonck M., Boudin M., and de Mulder G. 2010. The carbon origin of structural carbonate in bone apatite of cremated bones. Radiocarbon 52: 578-586.

Takala H., Sirviö T. 2003. Telkkälä, Muolaa - A multi-period dwelling site on the Karelian Isthmus. Fennoscandia Archaeologica XX: 55-78.

Tallavaara M. 2015. Humans under climate forcing How climate change shaped hunter-gatherer population dynamics in Europe 30000-4000 years ago. Helsinki.

Tallavaara M., Seppä H. 2012. Did the mid-Holocene environmental changes cause the boom and bust of hunter-gatherer population size in eastern Fennoscandia? The $\mathrm{Ho}^{-}$ locene 22: 215-225.

https://doi.org/10.1177/0959683611414937
Taylor R. E., Bar-Yosef 0. 2014. Radiocarbon dating. An archaeological perspective. Left Coast Press. Walnut Creek.

Tiitinen T. 2011. Liikettä ajassa ja paikassa - Lounais-Suomen muinaisrannat tarkastelussa. In K. Uotila (ed.), Avauksia Ala-Satakunnan esihistoriaan. Kåkenhus-kirjat nro 2. Eura Print Oy. Eura: 47-80.

Timofeev V. I., Zaitseva G. I., Lavento M., Dolukhanov P., and Halinen P. 2004. The radiocarbon datings of the Stone Age - Early Metal Period on the Karelian Isthmus. Geochronometria 23: 93-99.

Torvinen M. 1979. Liedon Kukkarkosken kivikautinen kalmisto. Suomen Museo 1978: 37-80.

Vanhatalo S. 1991. Nousiainen Rauanniittu. Kivikautisen asuinpaikan koekaivaus 1988 (Excavation of a Stone Age settlement site). Unpublished excavation report. Archives of the Finnish Heritage Agency, Helsinki, Finland. https://www.kyppi.fi/palveluikkuna/raportti/read/ asp/hae_liite.aspx?id=103348\&ttyyppi=pdf\&kansio_id= 538

2010. Nousiainen Kukonharju 2. Kivikautisen asuinpaikan koekaivaus 2010. (Excavation of a Stone Age settlement site). Excavation report not available until 5/2019. Archives of the Finnish Heritage Agency. Helsinki.

Varonen M. 2008. Valinnan vapautta kulttuurin kehyksissä: saviastian valmistusprosessi ja sen muutos Rääkkylän Vihin kampakeraamisen ajan asuinpaikalla. Unpublished MA dissertation. University of Helsinki. Department of Archaaeology.

https://helda.helsinki.fi/handle/10138/19525

Vikkula A. 1981. Vantaan Maarinkunnas-Stenkulla. Tutkimuksia Uskela-keramiikan alalta. Helsingin yliopiston arkeologian laitos. Moniste 27. Helsinki.

1987. The Stone Age graves of the Nästinristi site in Laitila, SW Finland. Suomen Museo 1986: 5-18.

Viljanmaa S. 2009. Punamultahauta Yli-Iin Kierikinkankaan kivikautiselta asuinpaikalta. In J. Ikäheimo, S. Lipponen (eds.), Ei kiveäkään kääntämättä: Juhlakirja Pentti Koivuselle. Pentti Koivusen juhlakirjatoimikunta. Oulu: 175-182.

Vybornov A. A., Moisin V. S., and Epimakhov A. V. 2014. Chronology of the Uralian Neolithic. Archaeology, Ethnology and Anthropology of Eurasia 42: 33-48. 